\title{
Primerjava dveh interdisciplinarnih, na učenca usmerjenih učnih pristopov za vpeljavo na področje matematike
}

Andreja Drobnič Vidic, Fakulteta za matematiko in fiziko Univerze v Ljubljani

\section{Vpeljava interdisciplinarnih, na učenca osredotočenih učnih pristopov v slovenski izobraževalni sistem}

U

čenje matematike s preiskovanjem je na novo vpeljan pojem v slovenskem matematičnem izobraževanju. Kot učitelj matematike sem želela natančno definicijo te inovacije. Je to nova metoda učenja, učna oblika, način poučevanja ali druge vrste učni izziv? Na področju izobraževanja v slovenskem jeziku težko najdemo učbenik ali knjigo, kjer bi pridobili sodobno terminologijo pojmov s področja didaktike. Ob pregledu tiskanih knjig in spletnih virov se zdi, da vlada na tem področju velika zmeda.

$\mathrm{V}$ nasprotju $\mathrm{z}$ enotno delitvijo učnih oblik $\mathrm{v}$ literaturi na frontalno, individualno, skupinsko učno obliko in delo v paru ali tandem (npr. Blažič et al., 2003; Tomić, 1999) sta delitev in imenovanje učnih pristopov, strategij, konceptov, inovacij pri pouku oziroma prijemov pri poučevanju zelo različna. Imena so odvisna od tega, ali obravnavamo poučevanje oziroma učenje pri pouku z metodološkega vidika, $\mathrm{z}$ vidika razvojne teorije, $\mathrm{z}$ vidika uporabe pri določenem predmetu ali kako drugače.

Pri predmetu Didaktične strategije na Filozofski fakulteti v Ljubljani, katerega vsebina je dostopna na spletu (Filozofska fakulteta Univerze v Ljubljani, 2020), izpostavljajo tri pristope sodobnega pouka: problemski pouk, sodelovalno učenje in projektno učno delo. V knjigi Didaktični modeli nemških didaktikov, prevedeni v slovenski jezik, namesto pristopov pouka ločujejo večkonceptov pouka. Avtorji visokošolskega učbenika Didaktika ločujejo več strategij pouka in omenjajo nejasnosti 
v razumevanju pojma didaktična strategija, ki se prepleta s pojmom učna metoda in s strategijo poučevanja (Blažič et al., 2003: str. 39). Razlikovati bi morali med strategijami in koncepti pouka: strategije pouka so načrtovani postopki, usmerjeni v izvajanje in doseganje konkretnih namenov in ciljev pouka; »koncept pouka ima v primerjavi s strategijo pouka več teoretičnih obeležij, medtem ko strategija ta obeležja praktično operacionalizira v vsebini, metodah in organizaciji učnih situacij, v učni aktivnosti učitelja in učencev«, kot lahko preberemo v spletnem slovarju Termania (2020). V učbeniku Osnove visokošolske didaktike (Tomić, 1999), ki ga poleg učbenika Didaktika večinoma navajajo kot osnovno literaturo pri učenju didaktike, načinov, strategij, konceptov, pouka ali pristopov, prijemov pri pouku ni omenjenih, opisan je le problemski pouk. V didaktičnih priporočilih veljavnega učnega načrta za matematiko za gimnazije navajajo, da različne učne pristope (npr. raziskovanje in reševanje matematičnih ter avtentičnih problemov) lahko omogočimo z informacijsko in komunikacijsko tehnologijo (Učni načrt Matematika, Gimnazija, 2008).

V učbeniku (Blažič et al., 2003) ločijo 8 strategij pouka, opisanih v Preglednici I, ki se v slovenski literaturi pogosto navajajo kot učni pristopi, ki so pripisani v drugem stolpcu Preglednice ı. V njej smo dodali tudi prevod, ki je najpogosteje naveden ob slovenskih zapisih. Seveda so nam posamezne besede razumljive: učenje izhaja iz učenca, poučevanje iz učitelja, pouk je organizirana interakcija učenja učencev in poučevanja učitelja ali bolj strokovno: »je načrten, organiziran in smotrn vzgojno-izobraževalni proces poučevanja, učenja in vzgajanja« (ibid.: str. 26). Pripis končnice učenje, poučevanje ali pouk je odvisen od tega, ali je v ospredju učenec in njegovo učenje ali učitelj in njegovo poučevanje. Kadar sta obe perspektivi enakovredni, uporabimo morda besedo pouk. V literaturi najdemo tako raziskovalni pouk kot raziskovalno učenje na primer. Več težav za neveščega je v razlikovanju pristopov, konceptov in strategij pouka, učenja, poučevanja.

Uporaba naštetih strategij pouka v Preglednici I je odvisna od razvojne stopnje učečega in od predmeta, ki ga učimo pri pouku. Ločnice med omenjenimi strategijami pouka, učenja so v literaturi težje dostopne, med njimi pa zasledimo vrsto povezav. Blažič in sodelavci navajajo, da naj bi bil odkrivajoči pouk bolj načelo, ki naj bi usmerjalo vse strategije pouka. Je zelo zahteven za učence, saj naj bi svobodno raziskovali in pridobivali nova spoznanja. Raziskovalni pouk je usposabljanje učencev za samostojni odkrivajoči pouk; projektni pouk je sestavni del raziskovalnega in tudi problemski pouk je podoben raziskovalnemu, le da je osredotočen na probleme (ibid.: str. 39-4I). 
A. DROBNIČ VIDIC • PRIMERJAVA DVEH INTERDISCIPLINARNIH UČNIH PRISTOPOV ...

Preglednica I: Strategije pouka, učni pristopi in angleški original.

\begin{tabular}{llll}
\multicolumn{1}{c}{ Strategije pouka } & \multicolumn{1}{c}{ Učni pristopi } & \multicolumn{1}{c}{ Angleško imenovanje } \\
I. & Odkrivajoči pouk & Odkrivajoče učenje & Discoverylearning \\
\hline 2. & Raziskovalni pouk & Raziskovalno učenje & Inquiry-based learning IBL \\
\hline 3. & Projektni pouk & Projektno učenje & Project-based learning PBL \\
\hline 4. & Problemski pouk & Problemsko (naravnano) učenje & Problem-based learning PBL \\
\hline 5. & Izkustveni pouk & Izkustveno učenje & Experientiallearning \\
\hline 6. & Ravnanjski(delovni) pouk & Delovno učenje & Learningby doing \\
\hline 7. & Programirani pouk & Programirano poučevanje & Programmed instruction \\
\hline 8. & Timski pouk & Timsko poučevanje & Teachingas a team \\
\hline
\end{tabular}

Prince in Felder (2006) na področju visokošolskega izobraževanja ločita učne pristope glede na induktivno ali deduktivno pot spoznavanja. Pri induktivni poti spoznavanja iz primerov in različnih aktivnosti učenci spoznajo splošno pravilo, medtem ko deduktivna pot spoznavanja pomeni, da podano splošno pravilo uporabimo na raznih primerih in pri raznih aktivnostih ter nadaljnjih sklepih. Avtorja menita, da pri induktivni poti učenci s pomočjo učitelja pridejo sami do novega znanja, medtem ko pri deduktivni poti učitelj najprej novo znanje poda, učenci pa ga preizkušajo in uporabijo v novih situacijah. Seveda poudarjata, da se v naravoslovju, inženirstvu in matematiki deduktivne ter induktivne poti spoznavanja prepletajo. Glede na način, ki pri učencih prevladuje pri usvajanju novega znanja, tudi učni pristope delita na induktivne in deduktivne. Pri deduktivnih, ki so bolj tradicionalni, govorita raje o poučevanju, pri induktivnih, kjer učenci generalizirajo novo spoznanje, pa govorita o učenju. Tako prve štiri učne pristope $\mathrm{v}$ Preglednici I uvrščata med tiste s prevladujočo induktivno potjo spoznavanja. Pri teh bomo tudi mi uporabili besedo učenje, čeprav gre za interakcijo učenja in poučevanja.

Avtorja postavljata raziskovalno učenje (IBL) za krovni učni pristop, ki vključuje odkrivajoče, projektno $(\mathrm{PjBL})$ in problemsko (naravnano) učenje (PBL). Omenjenim pristopom iščeta razlike v končnem produktu oziroma v izidu učenja oz. poučevanja, v količini vodenja s strani učitelja in v ocenjevanju ter ugotavljata, da se marsikje razlike zabrišejo. Če namreč odkrivajoče učenje dalje delimo na vodeno in nevodeno odkrivajoče učenje, se vodenega težko loči od ostalih štirih učnih pristopov. Medtem ko so za IBL značilna zanimiva vprašanja iz realnega življenja (realne situacije), na katera učenci iščejo odgovore (in si postavljajo nova vprašanja) ter preko njih pridobijo nova spoznanja o zastavljeni situaciji, so za PBL značilni problemi iz vsakdanjega življenja, ki sprožijo učenje 
novega znanja, ki je potrebno za rešitev problema; pri $\mathrm{PjBL}$ so v ospredju interdisciplinarni obsežnejši problemi - tako imenovani projekti, podobni tistim v delovnem okolju. Vprašanja si seveda zastavljajo tudi učenci pri $\mathrm{PBL}$ in PjBL in raziskovanje situacije pomeni lahko tudi reševanje problema ali izzove opravljanje večjega projekta, ki zahteva obširno analizo in zaključno predstavitev (ibid.), zato so argumenti za krovni pristop lahko upravičeni. $V$ svetovno priznanih znanstvenih revijah podajajo kritiko o nepravilni rabi in razumevanju omenjenih učnih pristopov (Hmelo-Silver et al., 2007) in poudarjajo, da pri pouku v realizaciji ti pristopi niso minimalno vodeni ali celo nevodeni s strani učitelja, temveč ima učitelj pomembno vlogo pri izvajanju takega učnega procesa kot oblikovalec pouka, usmerjevalec, motivator ipd.

V Sloveniji se med sodobnimi učnimi pristopi matematike večkrat omenjajo izkustveno učenje, raziskovalno učenje in odkrivajoče učenje $s$ prevladujočo induktivno potjo spoznavanja, vendar tudi pri predmetu samem omenjenih pristopov ne zmoremo natančno ločevati (Kmetič in Sirnik, 20Io). Slovenski prevod za IBL v eni sami slovenski izobraževalni instituciji je pri različnih STEM predmetih (predmeti naravoslovja, tehnike, tehnologije, inženirstva in matematike) različen:

- učenje s poizvedovanjem oz. poizvedovalno učenje pri tehniki (Jenstrle, 2017),

- učenje z raziskovanjem pri naravoslovju (Petek, 20I2),

- učenje spreiskovanjem pri matematiki (Suban, 2017).

Učitelj matematike, ki si želi nekoliko bolj spoznati nov način, pristop, izziv, prijem, strategijo pouka, učenja oz. poučevanja in želi z njim matematiko povezati z drugimi predmeti, je lahko upravičeno zmeden že samo zaradi prevodov, kaj šele zavoljo slabih vsebinskih razlikovanj in morebitne nepravilne rabe didaktičnih pojmov.

V nadaljevanju bomo primerjali dva učna pristopa, kot bomo poimenovali inovaciji PBL in IBL. Prvega, ker smo ga pred leti sami uvajali v poučevanje statistike, ki je vsaj na ravni srednje šole del matematike (Drobnič Vidic, 20II, 2017), in slednjega, ker je postal zelo promoviran v slovenskem poučevanju matematike $\mathrm{v}$ zadnjih letih. Po teoretični primerjavi obeh pristopov na podlagi tuje literature bomo preverili, koliko objav o obeh pristopih najdemo $\mathrm{v}$ slovenski literaturi, in preverili, kakšne prevode uporabljajo avtorji. Nato pa bomo na podlagi analize tujih objav ugotavljali, kateri pristop se bolj uporablja v matematiki v primerjavi z naravoslovjem, in skušali podati smernice za učinkovit učni pristop matematike. 


\section{IBL in PBL pri matematiki}

$\mathrm{V}$ poučevanju matematike so se $\mathrm{v}$ Evropi oblikovala naslednja središča, ki poudarjajo svojevrstne načine sodobnih poti spoznavanja pri matematiki in so bila predstavljena na največjem mednarodnem kongresu o matematičnem izobraževanju ICME-ı3 (Bloom, 2016):

- Michèle Artigue (prednik: Brousseau): francoska šola učenja matematike, imenovana Didactical Engeeniring,

- Marja van den Heuvel-Panhuizen (prednik: Freudenthal): nizozemska šola učenja matematike, imenovana Realistic Mathemamatics Education,

- Rudolf Sträßer (prednik: Kirsch): nemška šola učenja matematike, imenovana Stoffdidaktik in kasneje pogosto izpostavljeno matematično modeliranje,

- Maria Alessandra Mariotti (prednica: Castelnuovo): italijanska šola učenja matematike $s$ sodelovalnim učenjem $\mathrm{v}$ multikulturnem okolju in akcijskim raziskovanjem.

Prav vsako od sodobnih evropskih središč razvoja matematičnega izobraževanja ima teoretična izhodišča, ki omogočajo implementacijo IBL (Artigue in Blomhøj, 2013): francoska šola $\mathrm{z}$ raziskovalnim pristopom do reševanja problemov, nizozemska $\mathrm{z}$ matematizacijo kot osnovno zahtevo za učinkovito reševanje realnih problemov, nemška z osredotočenostjo na snov, dostopno učencem, in z matematičnim modeliranjem realnega sveta za njegovo razumevanje ter italijanska s sodelovalnim učenjem kot učinkovitem načinu reševanja interdisciplinarnih kompleksnih situacij v multikulturnem okolju.

\section{Karakteristike IBL}

Pojem IBL se nanaša na učenje oz. poučevanje, osredotočeno na učenca, pri katerem učenci postavljajo vprašanja, raziskujejo določene situacije in razvijajo lastne poti do novih spoznanj. Učenci preiskujejo situacijo tako, da jo opazujejo, berejo dodatno literaturo in iščejo že znane informacije, planirajo raziskavo, eksperimentirajo, uporabljajo različna orodja za analizo in interpretacijo podatkov ter diskutirajo o možnih rešitvah. Pri pouku v naravoslovju je pri IBL v ospredju učenje po ciklu petih e-jev: engagement, exploration, explanation, elaboration in evaluation (Oguz-Unver in Arabacioglu, 20II), kar predstavlja cikel opazovanja situacije (problema), njenega raziskovanja, razjasnitve situacije oziroma pojava ali rešitve problema, zapisovanja spoznanj, argumentov in predstavitev ter ocena opravljenega dela. Preiskovanje zahteva tako pridobivanje znanih informacij in predpostavk, ki so lahko tudi iz drugih področij in ne le iz področja, kjer 
situacijo preučujemo, kot tudi uporabo kritičnega razmišljanja in logičnega sklepanja ter uporabo in vključevanje dodatnih in alternativnih razlag, da se pridobi nova spoznanja, saj znanstveno raziskovanje vključuje vse to (Maaß in Artigue, 2013). Za preiskovanje je torej značilno: postavljanje vprašanj, interdisciplinarno iskanje virov in novih idej, reševanje problemov, modeliranje, matematizacija, raziskovanje, analiza dokumentov in podatkov, eksperimentiranje, testiranje, razlaga, razmišljanje, argumentiranje, dokazovanje, strukturiranje novega znanja, povezovanje, predstavitev in diskusija (Artigue in Blomhøj, 2013; Suban, 2017).

$\mathrm{Za}$ te vrste procesov je pogosto potrebno sodelovanje in delo $\mathrm{v}$ skupinah, novo vlogo pa mora prevzeti tudi učitelj, ki spodbuja učence k preiskovanju, odkrivanju lastnih poti do spoznanj in podpira sodelovalno delo. Učitelj usmerja učence k postavljanju vprašanj, spodbuja jih k uporabi njihovega predznanja pri preiskovanju, upravlja delo majhnih skupin in diskusijo, podpira in usmerja individualno učenčevo delo, ko je to potrebno. Pomaga jim vzpostaviti povezave med njihovimi dognanji in splošnimi (matematičnimi) zakonitostmi (Maaß in Artigue, 2013).

\section{Karakteristike PBL}

Problemsko naravnano učenje (PBL) je na področju medicine vpeljal Barrows na univerzi McMaster konec sedemdesetih let prejšnjega stoletja. To je na učenca usmerjeno učenje oz. poučevanje, pri katerem problemi sprožijo učenje nove snovi. Pred začetkom obravnave snovi se namreč majhnim skupinam učencev postavi problem (situacija). Ti morajo problem razčleniti in ugotoviti, kaj problem od njih zahteva - katero novo znanje morajo osvojiti, da bodo problem rešili. Problem naj bo postavljen iz realnega sveta oziroma stroke, da mlade motivira, in mora biti seveda tak, da sproži učenje nove snovi. To slednje ločuje PBL od širšega problemskega učenja, kjer je problem lahko teoretični ali realni, ki sproži učenje nove snovi ali pa le razvija veščine reševanja problemov.

Za reševanje problema sta navadno na voljo dve fazi. $V$ prvi fazi $s$ petimi koraki pri pouku se učenci v majhnih skupinah (navadno okoli 5) soočijo s problemom, ugotovijo, kaj od njih zahteva, in z deževanjem idej ugotovijo, katero že pridobljeno znanje jim morda lahko pomaga rešiti problem. Seveda morajo ugotoviti, česa še ne znajo, katere informacije je treba še pridobiti, da bi problem lahko rešili. $S$ tem se prva faza zaključi in učenci samostojno izven pouka pridobijo nove informacije. $\mathrm{V}$ drugi fazi z dvema korakoma nove informacije $\mathrm{v}$ skupini zberejo in $\mathrm{z}$ njimi rešijo problem. Rešitev zapišejo, lahko tudi predstavijo in kritično ovrednotijo. Celoten proces imenujejo tudi cikel 7 korakov (Boud in Feletti, 1998) in je predstavljen $v$ prispevku v prilogi na konkretnem primeru pri 
spoznavanju statističnih vsebin pri matematiki v gimnaziji (in preoblikovan za IBL s ciklom s e-jev).

Učitelj prevzame vlogo usmerjevalca in ne posredovalca novega znanja. Učence usmerja, sprašuje, pomaga, da ne bi zašli na stranpoti, jim zastavlja vprašanja in nanje tudi odgovarja, vendar ne tako, da bi razkril rešitev problema, ampak tako, da učenci aktivno rešujejo problem naprej. Do rešitve problema naj pridejo učenci sami s pomočjo lastnega predznanja in interdisciplinarnega povezovanja področij. Pri pravem PBL snov kurikuluma narekujejo problemi in ne obratno. Znanje, ki je potrebno za reševanje problemov stroke, je tisto, ki ga morajo mladi osvojiti, kar se nanaša predvsem na visokošolsko izobraževanje.

\section{Primerjava IBL in PBL}

Že tuji raziskovalci so se spraševali, kakšne so podobnosti in razlike med IBL in PBL ter med nekaterimi drugimi aktivnimi interdisciplinarnimi načini učenja (Feletti, 2006; Hmelo-Silver et al., 2007; Oguz-Unver in Arabacioglu, 20ı1; Prince in Felder, 2006; Spronken-Smith, 2012). Oba pristopa sta primer aktivnega učenja, ki v ospredje postavljata učenca $\mathrm{z}$ njegovim učnim procesom in ne učitelja. Obema je značilno preiskovanje, pri PBL je to preiskovanje odprtega problema iz življenja ali stroke, pri IBL preiskovanje neke situacije, pojava, vprašanja ali tudi problema, lahko teoretičnega ali iz življenja oziroma stroke. S tega vidika je IBL krovna metoda. Prav tako naj bi aktivnosti pri PBL potekale daljše obdobje in konstantno pri obravnavi nove snovi pri pouku in lahko združujejo več predmetov, medtem ko za IBL te zahteve eksplicitno ni podane, a že ime pove, naj bi učenje temeljilo na raziskovanju, torej naj bi ta aktivnost potekala dalj časa. Pisne zahteve in priporočila za PBL glede zastavljanja realnih problemov, ki sprožijo učenje snovi v daljšem učnem obdobju, kot je šolsko leto, in interdisciplinarno povezovanje raznih predmetov so večji kot pri IBL. Natančnejša primerjava med IBL in PBL je v mnogih karakteristikah podana $\mathrm{v}$ Preglednici 2, ki smo jo zapisali na podlagi trditev v primerjalnih študijah (Hmelo-Silver et al., 2007; Oguz-Unver in Arabacioglu, 20II; Prince in Felder, 2006; Spronken-Smith, 2012).

Oba učna pristopa se teoretično močno razlikujeta po nivojih poučevanja in po najprimernejših področjih učenja (Preglednica 2). IBL naj bi bil značilen za osnovnošolski nivo, PBL za študij. Matematika ni poudarjena ne pri IBL ne pri PBL, so pa naloge učencev, vodilo in specifični izidi pri IBL bolj pisani na kožo naravoslovnemu načinu raziskovanja pojavov. Cikel sedmih korakov je pri reševanju problema pri PBL nekoliko podrobneje razčlenjen kot cikel 5 e-jev pri preiskovanju problema $\mathrm{z}$ IBL, oba načina aktivnega reševanja sta predstavljena v prilogi, seveda sta 
Preglednica 2: Podobnosti in razlike med IBL in PBL.

\begin{tabular}{|c|c|c|}
\hline Karakteristike & IBL & PBL \\
\hline Osrednja dejavnost & Preiskovanje zastavljene situacije & $\begin{array}{l}\text { Reševanje problema, ki sproži učenje } \\
\text { nove snovi }\end{array}$ \\
\hline Predmet dejavnosti & Situacija (pojav), problem & Nestrukturirani problem \\
\hline Cilj & Spoznavanje nove snovi & Spoznavanje nove snovi \\
\hline Vodilo & $\begin{array}{l}\text { Učenje preko neposrednega opazo- } \\
\text { vanja in preiskovanja kot znanstve- } \\
\text { ne raziskave. }\end{array}$ & $\begin{array}{l}\text { Učenje preko realnega problema z } \\
\text { uporabo lastnega predznanja in no- } \\
\text { vih informacij. }\end{array}$ \\
\hline Pionirji & Dewey, Schwab & Dewey, Barrows \\
\hline Način učenja & $\begin{array}{l}\text { Osredotočeno na učenca, cikel pe- } \\
\text { tih E-jev. }\end{array}$ & $\begin{array}{l}\text { Osredotočeno na učenca, cikel sed- } \\
\text { mih korakov. }\end{array}$ \\
\hline Učna oblika & $\begin{array}{l}\text { Lahko v eni skupini, v manjših skupi- } \\
\text { nah, individualno, v paru }\end{array}$ & V manjših skupinah $(4-6)$ \\
\hline Predznanje & $\begin{array}{l}\text { Ni nujno potrebno, novo znanje se } \\
\text { lahko pridobi z opazovanjem. }\end{array}$ & $\begin{array}{l}\text { Je nujno potrebno, na njem se gradi } \\
\text { znanje, potrebno za rešitev problema. }\end{array}$ \\
\hline Naloga učitelja & Usmerjevalec, vir vprašanj, vodja & Usmerjevalec, tutor \\
\hline Naloga učencev & $\begin{array}{l}\text { Postavljajo vprašanja, pojasnjujejo, } \\
\text { oblikujejo hipoteze, interpretirajo, } \\
\text { sprašujejo in odgovarjajo... }\end{array}$ & $\begin{array}{l}\text { Oblikujejo naloge, iščejo nove in- } \\
\text { formacije, so vir vprašanj, obliku- } \\
\text { jejo učne cilje, določajo rešitve } \\
\text { problema... }\end{array}$ \\
\hline Nivo izobraževanja & $\begin{array}{l}\text { Najprimernejši za osnovnošolski } \\
\text { nivo }\end{array}$ & Najprimernejši za visokošolski nivo \\
\hline $\begin{array}{l}\text { Najprimernejše } \\
\text { področje } \\
\text { izobraževanja }\end{array}$ & Za vsa področja, posebej naravoslovje & $\begin{array}{l}\text { Za vsa področja, posebej za medici- } \\
\text { no, inženirstvo }\end{array}$ \\
\hline Specifični izidi & $\begin{array}{l}\text { Razumevanje konceptov znanstve- } \\
\text { nega dela, uporaba znanja, vzpodbu- } \\
\text { janje kreativnosti }\end{array}$ & $\begin{array}{l}\text { Učinkovito reševanje realnih proble- } \\
\text { mov, pridobivanje veščin samostoj- } \\
\text { nega in vseživljenjskega učenja, upo- } \\
\text { raba znanja }\end{array}$ \\
\hline
\end{tabular}

oba načina dela le priporočena, uporabljajo se tudi drugi. Predznanje je pri PBL nujno potrebno, pri IBL lahko učenci potrebno predznanje za delo pridobijo tudi z opazovanjem. Pri matematiki je pogosto pri zastavljeni situaciji potrebno poleg opazovanja oz. preiskovanja situacije uporabiti določeno matematično predznanje (Artigue in Blomhøj, 2013). S tega vidika je IBL pri matematiki podoben PBL, ki ima v določenih pogledih strožje zahteve.

$\mathrm{V}$ prispevku želimo ugotoviti, kako pogosto in na katerih področjih se omenjena pristopa preučujeta ali uporabljata v slovenskih člankih, nato pa napravimo primerjavo tudi pri specifični tuji literaturi. V njej želimo ugotoviti, kako pogosta sta učna pristopa $v$ matematiki glede na 
naravoslovje, saj bi na podlagi tega lahko izluščili, kateri od omenjenih pristopov je primernejši za področje matematike ali za njuno interdisciplinarno povezavo.

\section{Metoda dela}

Uporabljamo kavzalno-neeksperimentalno metodo za primerjavo dveh učnih pristopov. Ker naš namen ni ugotavljanje učinkovitosti obeh pristopov, ampak ugotavljanje smiselnosti umestitve v poučevanje matematike, nismo izbrali metaanalize, ki zahteva statistično analizo eksperimentalnih raziskav, ampak študijo literature obeh pristopov tako na slovenskem področju kot širše.

Za kratek pregled slovenskih prispevkov o IBL in PBL smo se odločili zato, da preverimo, ali se težave v slovenskih zapisih danih učnih pristopov, ki smo jih omenili, odražajo tudi v prispevkih. Želeli smo ugotoviti, ali se za preučevana učna pristopa uporabljajo kateri drugi izrazi in ali se v tem delu omenjeni besedni sklopi za IBL ali PBL uporabljajo tudi za kakšen drug učni pristop. Prav tako smo želeli ugotoviti, v kolikšni meri se dani pristop uveljavlja na področju matematike oziroma ali teoretične domneve o naravoslovju kot značilnem področju uveljavljanja IBL slovenski prispevki potrjujejo.

Seveda je slovensko področje izobraževanja majhno in dejavnost na določenem pedagoškem področju je lahko odraz manjših skupin raziskovalcev, ki uvajajo neko inovacijo. Zato smo želeli dobiti vpogled, kako je $\mathrm{z}$ obema obravnavanima učnima pristopoma na področju matematike in naravoslovja v tujini. S kvalitativno analizo visokokakovostnih tujih prispevkov smo želeli ugotoviti ne le področja vključevanja učnega pristopa, ampak tudi izobraževalni nivo, kvaliteto opravljene raziskave, vrsto raziskave, metodo dela, udeležence $\mathrm{v}$ raziskavi in druge značilnosti, ki bi nam osvetlile uporabo obeh pristopov na področju matematike.

Metaanalize navadno preučujejo učinek določenega načina poučevanja pri empiričnih raziskavah z eksperimentalno in kontrolno skupino. Zaradi majhne količine tovrstnih raziskav avtorji pogosto segajo poleg visokokakovostnih revij tudi po neobjavljenih delih avtorjev posebnih tujejezičnih skupin (Demirel in Dagyar, 2016). V metaanalizi vseh vrst na učenca osredotočenih načinov učenja je bilo v študiji (Savelsbergh et al., 2016) analiziranih skupno 56 raziskav za analizo, kar je za vse vrste na učenca osredotočenih učnih pristopov bore malo. Pri takem preučevanju so spet drugi avtorji uporabili posebno statistično metaanalizo, ki je omogočala vključitev eksperimentalnih raziskav s samo eno preučevano skupino s podatki pred testom in po njem (Belland et al., 2017), česar mnogi avtorji ne odobravajo. Druge vrste raziskav, kot so študija primera, 
opazovanje, primerjalna študija in podobno, $\mathrm{v}$ metaanalizah navadno niso zajete, čeprav nam dajo lahko kvalitetne informacije o danem učnem pristopu. Res je, da so eksperimentalne raziskave za vpogled v učinkovitost danega učnega pristopa najpomembnejše, vendar se pogosto zgodi, da rezultati, kjer eksperimentalna skupina ni imela zadovoljivega učinka, ostanejo neobjavljeni. Tudi mnoge karakteristike realizacije učnega pristopa kot so: način izvajanja pristopa (pri pouku ali izven njega), količina priprav učitelja za realizacijo inovacije, vloga učitelja, uporabljeni učni material in podobno, $\mathrm{v}$ metaanalizah najpogosteje niso podane (Belland et al., 2017; Demirel in Dagyar, 2016). Da bi ugotovili, kateri učni pristop se na danem področju pogosteje uporablja in ima večjo popularnost, imajo neeksperimentalne raziskave prav tako veliko vlogo kot eksperimentalne. Vključevanje tovrstnih raziskav omogoča sistematični pregled (znanstvene) literature, ki so ga za posamezni pristop že opravili na področju naravoslovja (Brown, 2017; Lin et al., 2012).

Da bi zajeli tudi neeksperimentalne raziskave in pridobili vpogled $\mathrm{v}$ pojavitev preučevanih dveh učnih pristopov $\mathrm{v}$ matematiki glede na naravoslovje, smo se $\mathrm{v}$ pričujočem delu omejili na sistematični pregled specifične literature z vsebinsko analizo (Vogrinc, 2008: str. 57). Na ta način smo želeli ugotoviti:

- Ali sta obravnavana dolgoročna učna pristopa IBL in PBL pogosteje uporabljena (ne pa nujno učinkovitejša) v naravoslovju ali v matematiki glede na s-letna obdobja?

- Kakšne so razlike med dolgoročnima pristopoma na področju matematike glede na kvaliteto obravnave, nivo poučevanja, vrste raziskovalne metode in udeležence $\mathrm{v}$ učnem pristopu glede na področje naravoslovja?

Za odgovore na raziskovalna vprašanja smo skrbno izbrali prispevke na področju matematike in naravoslovja, kjer je IBL in/ali PBL središče preučevanja, in določili, na katerem področju je pristop obravnavan. $\mathrm{Na}$ slovenskem področju smo za to uporabili knjižnični informacijski sistem Cobiss, ki združuje raziskovalce in učitelje različnih področij. Tujo literaturo smo omejili na pregled prispevkov $\mathrm{v}$ takih svetovno uveljavljenih revijah s področja izobraževanja, ki enakovredno objavljajo prispevke s področja matematike in naravoslovja. Tako smo marca 2018 v MetaIskalnik ${ }^{1}$ vnesli besede science, math in education. Od sedmih najdenih revij sta bili le dve taki, ki sta omogočali poln dostop do člankov, izhajali vsaj to let in sta imeli faktor vpliva: International journal of science and mathematics

I http://home.izum.si/izum/ft_baze/ 
education (IJSME) in Euroasia journal of mathematics, science and technology education. Odločili smo se, da pregledamo prispevke v prvi reviji, ki je edina omogočala hkratno iskanje po besednih sklopih, saj smo želeli doseči, da sta matematika in naravoslovje kot didaktični področji vpeljevanja inovacij enakovredno zastopani.

Selekcioniranim prispevkom tuje revije smo določili kvaliteto obravnave, področje izobraževanja, izobraževalni nivo obravnavanega učnega pristopa, ki je lahko osnovna, srednja šola ali univerza. Če nivo v raziskavi ni en sam, smo zapisali najnižji izobraževalni nivo, ki je omenjen. Nivo se nanaša na snov, ki je bila $\mathrm{z}$ učnim pristopom zajeta, ne na preučevane osebe. Če so z raziskavo preučevali kakovost vključevanja pristopa v osnovno šolo pri naravoslovju z nalogami, ki so jih sestavljali prihodnji učitelji, smo izbrali osnovnošolski nivo pristopa in ne univerzitetnega, saj tja pristop vključujemo. Ločili smo tri vrste raziskav: kvalitativno, kvantitativno in mešano, ter naslednje raziskovalne metode, ki so jih avtorji prispevkov uporabili: kavzalno-eksperimentalno, kvazi kavzalno-eksperimentalno, kavzalno-neeksperimentalno in deskriptivno metodo. $S$ prvo metodo avtorji primerjajo učinkovitost eksperimentalnega faktorja z eksperimentalno in kontrolno skupino, $\mathrm{z}$ drugo pa razliko $\mathrm{v}$ učinkovitosti le-tega pred in po njegovem vnosu. Take raziskave so največkrat kvantitativne. Kavzalno-neeksperimentalne metode, ki vključujejo najpogosteje študijo primera ali analizo vprašalnikov, pa so lahko kvalitativne ali kvantitativne. Nato smo določili tudi preučevane osebe, ki so lahko učenci, učitelji oziroma prihodnji učitelji, ki se za poklic še izobražujejo, lahko pa so akterji učitelji in učenci skupaj. Nato smo najpomembnejše prispevke z uvajanjem učnega pristopa na področje matematike tudi podrobneje vsebinsko analizirali.

Metoda je preverljiva in zanesljiva, saj so vsi prispevki javno dostopni in so podane vse karakteristike selekcije in analize. Vse izbrane prispevke in njim določene karakteristike smo ponovno analizirali po enem letu, ko smo za primerjavo na podoben način selekcionirali prispevke baze $W e b$ of Science (Wos) z namenom nadaljnje raziskave. To omogoča večjo kredibilnost raziskave, ki je zaradi vpetosti rezultatov neposredno v prakso zadovoljive veljavnosti. Primerjava izsledkov s teoretičnimi izhodišči ponuja boljšo triangulacijo, ki pa bi se jo dalo še izboljšati z dodatnimi metodami dela, kot sta intervju ali druga študija literature (Vogrinc, 2008).

V zaključku smo povzeli težave slovenskih prevodov pri seznanjanju $\mathrm{z}$ danim učnim pristopom, podali omejitve raziskave in dodali smernice za vključevanje pristopov na področju matematike in svetovali, na kaj moramo biti pozorni, ko iščemo zase najprimernejšo inovacijo kot učitelji, in ko o inovaciji učinkovito poročamo kot raziskovalci. 


\section{Rezultati}

\section{Uporaba IBL in PBL v slovenski literaturi}

V Cobiss smo decembra 2019 preverili, kako pogosto $\mathrm{v}$ člankih pišejo o IBL in PBL. V ukazno iskanje člankov smo zaporedoma vnesli besedne sklope: raziskovalno učenje, učenje $\mathrm{z}$ raziskovanjem, preiskovalno učenje, učenje s preiskovanjem, poizvedovalno učenje in učenje $s$ poizvedovanjem, kar naj bi po nekaterih virih (Jenstrle, 2017; Petek, 2012; Suban, 2017) ustrezalo kratici IBL. Zatem smo vnesli še besedne sklope: problemsko naravnano učenje, problemsko zasnovano učenje, problemsko učenje in učenje s problemi ter učenje $\mathrm{z}$ reševanjem problemov, ki naj bi morda ustrezali slovenskemu prevodu PBL (Drobnič Vidic, 2005). Ugotavljali smo število slovenskih in tujejezičnih prispevkov, obdobje objave, prevode za učni pristop in področje poučevanja. Pri slednjem smo ločili področja: matematika, naravoslovje, tehnika oz. tehnologija, STEM, druga področja (z oznako »drugo «) in prispevke, pri katerih izobraževalno področje ni izpostavljeno in se učni pristop obravnava splošno (z oznako»vse «).

Za prva dva besedna sklopa smo dobili iı zadetkov (med njimi tudi zbornike s konferenc). Med temi zadetki je 84,4 \% prispevkov pisanih v slovenskem jeziku, kar kaže Preglednica 3, tujejezični so pisani v angleškem jeziku. Razen petih so vsi objavljeni v dvajsetem stoletju. Kar 86 prispevkov je iz naravoslovja, 4 iz matematike, 5 iz tehnike oz. tehnologije, I iz STEM, 5 iz drugih področij (predvsem zgodovine) in Is je splošnih prispevkov (Preglednica 3). Od teh II6 prispevkov jih ima le slabih io \% prevod inquiry-based learning in enak odstotek prispevkov ima drugačnega, ostali slovenski prispevki pa nimajo angleškega prevoda. Pojavljajo se prevodi research-based approach, learning through research, research learning, research-based learning ali scientific learning. Besedni sklop učenje s preiskovanjem je najden v Cobiss le v 4 člankih, vsi so objavljeni v letu 2017 in v 2018, vsi prevodi so inquiry-based learning in vsi prispevki se nanašajo na matematiko. Dalje je besedni sklop učenje s poizvedovanjem uporabljen $\mathrm{v}$ enem članku iz leta 2019 in trije članki preučujejo poizvedovalno učenje. Vsi so bili objavljeni v letih 2014 in 2015 ter se nanašajo na področje tehnike oz. tehnologije. Skupno je kar 69 \% prispevkov o IBL na področju naravoslovja, I2 \% splošnih prispevkov, 7 \% na področju tehnike oz. tehnologije in $6 \%$ na področju matematike (ostalo STEM in vse).

Besedni sklop problemsko naravnano učenje za PBL je najden v 23 člankih, objavljenih med 200 in 2012 . Med njimi je $57 \%$ slovenskih prispevkov. Največ prispevkov ta učni pristop uporablja na drugih področjih, ki v Preglednici 3 niso izpostavljena. Po en je na področju naravoslovja in matematike. Le štirje članki imenujejo PBL kot problemsko zasnovano 196 
Preglednica 3: Število prispevkov o IBL in PBL po področjih:

naravoslovje, matematika, tehnika/tehnologija, STEM, druga področja in vsa področja.

\begin{tabular}{|c|c|c|c|c|c|c|c|c|}
\hline Besedni sklopi & Število & Jezik & Nar & Mat & Teh & STEM & Drugo & Vse \\
\hline \multirow{2}{*}{$\begin{array}{l}\text { Učenje } \\
\text { z raziskovanjem }\end{array}$} & \multirow{2}{*}{40} & SL: 3I & 26 & & & & & 5 \\
\hline & & $\mathrm{TJ}: 9$ & 6 & I & 2 & & & \\
\hline \multirow{2}{*}{$\begin{array}{l}\text { Raziskovalno } \\
\text { učenje }\end{array}$} & \multirow{2}{*}{76} & SL: 67 & 47 & 3 & 3 & & 5 & 9 \\
\hline & & TJ: 9 & 7 & & & I & & I \\
\hline \multirow{2}{*}{$\begin{array}{l}\text { Učenje } \\
\text { s preiskovanjem }\end{array}$} & \multirow{2}{*}{4} & SL: 3 & & 3 & & & & \\
\hline & & TJ: I & & I & & & & \\
\hline $\begin{array}{l}\text { Preiskovalno } \\
\text { učenje }\end{array}$ & $\circ$ & & & & & & & \\
\hline \multirow{2}{*}{$\begin{array}{l}\text { Učenje } \\
\text { s poizvedovanjem }\end{array}$} & \multirow{2}{*}{ I } & SL: I & & & I & & & \\
\hline & & $\mathrm{TJ}: \circ$ & & & & & & \\
\hline \multirow{2}{*}{$\begin{array}{l}\text { Poizvedovalno } \\
\text { učenje }\end{array}$} & \multirow{2}{*}{3} & SL:3 & & & 3 & & & \\
\hline & & $\mathrm{TJ}: \circ$ & & & & & & \\
\hline Skupaj IBL & 124 & $104+19$ & 86 & 8 & 9 & I & 5 & I5 \\
\hline \multirow{2}{*}{$\begin{array}{l}\text { Problemsko na- } \\
\text { ravnano učenje }\end{array}$} & \multirow{2}{*}{23} & SL: 13 & I & I & & & 8 & 3 \\
\hline & & TJ: 10 & & I & & & 6 & 3 \\
\hline \multirow{2}{*}{$\begin{array}{l}\text { Problemsko za- } \\
\text { snovano učenje }\end{array}$} & \multirow{2}{*}{3} & SL: 3 & & I & & & 2 & \\
\hline & & $\mathrm{TJ}: \circ$ & & & & & $\circ$ & \\
\hline \multirow{2}{*}{$\begin{array}{l}\text { Problemsko } \\
\text { učenje }\end{array}$} & \multirow{2}{*}{49} & SL:25 & 2 & I & I & & 8 & 13 \\
\hline & & $\mathrm{TJ}: 24$ & 3 & 2 & 7 & & 8 & 4 \\
\hline $\begin{array}{l}\text { Učenje } \\
\text { s problemi }\end{array}$ & $\circ$ & & & & & & & \\
\hline Skupaj PBL & 75 & $4 I+34$ & 6 & 6 & 8 & $\circ$ & 32 & 23 \\
\hline $\begin{array}{l}\text { Skupaj IBL } \\
\text { PBL }\end{array}$ & 199 & $145+53$ & 92 & I 4 & 17 & $\mathbf{I}$ & 37 & 38 \\
\hline
\end{tabular}

učenje (od tega I angleški) na področju matematike, inženirstva in zdravstvene nege. Ko smo vnesli besedni sklop problemsko učenje, smo dobili 49 zadetkov, od tega 5I \% slovenskih. Čeprav je problemsko učenje lahko uporabljeno širše kot pojem metode pri pouku, ki je zajeta le krajši čas oz. del učne ure in ne gre za učni pristop, ki se uporablja pri učenju kontinuirano dalj časa, ima kar $55 \%$ prispevkov angleški prevod problem-based learning, torej PBL, 35 \% jih nima angleškega prevoda, po enkrat pa se 
pojavijo prevodi: problem-based teaching, inquiry-based teaching, learning by doing, experiental learning, project work in problem-based scenarios. Pet prispevkov je objavljenih od 1990 do 1996 in ti prispevki na spletu niso dosegljivi, nimajo prevoda, med njimi sta tudi prispevka dr. Strmčnika, ki uvaja problemsko učenje med ostale učne pristope in poudarja, da lahko ta način poučevanja poteka le del učne ure, lahko individualno ali v paru in torej ne gre za pravi PBL. Ostali članki so bili izdani od leta 2000 do 2019 in najpogosteje področja ni izpostavljenega ( $35 \%)$ ali pa je preučevanje usmerjeno na druga področja visokošolskega izobraževanja (33\%). $\mathrm{Za}$ besedni sklop učenje $s$ problemi in za učenje $\mathrm{z}$ reševanjem problemov v Cobiss ne najdemo nobenega prispevka. Skupno kar 43 \% PBL prispevkov pokriva druga področja, predvsem so to medicina, zdravstvena nega in tuji jezik stroke, $30 \%$ je splošnih prispevkov, kjer področje ni določeno, II \% prispevkov je na področju tehnike oz. tehnologije in po $8 \%$ na področju matematike in naravoslovja (Preglednica 3).

Seveda lahko pedagogi-raziskovalci uporabljajo tudi drugačno besedno zvezo za vsako od preučevanih inovacij. V Cobiss smo zato preverili še, koliko prispevkov se nanaša na angleško besedno zvezo inquiry-based learning in koliko na problem-based learning. Točno 27 člankov preučuje inquiry-based learning (torej so avtorji večinoma slovenski), od tega je 37 $\%$ prispevkov slovenskih. Prispevki so od leta 2010 do 2019 , od tega je I 4 prispevkov pri naravoslovju, 8 pri tehniki oz. tehnologiji, 2 prispevka sta splošna (Vse), po I pa obravnava matematiko, STEM in drugo področje. Seveda je med temi prispevki že precej takih, ki smo jih našli preko slovenskih besednih zvez, saj imajo angleški prevod. Nekaj teh prispevkov pa slovenskega prevoda nima. Novih slovenskih prevodov za IBL pri pregledu teh prispevkov nismo našli, razen imena raziskovalni pristop ali pouk namesto raziskovalno učenje.

Prispevkov z besedno zvezo problem-based learning je I29, od tega 30 $\%$ slovenskih. Prispevki so od leta 1998 dalje (do leta 2000 je pet člankov). Le 6 prispevkov je na področju naravoslovja, II pri matematiki (vključena statistika), I2 pri tehniki oz. tehnologiji, 2 na STEM področju, 29 je splošnih prispevkov in 69 prispevkov je objavljenih na drugih področjih, predvsem na področju medicine, zdravstvene nege, tujega jezika stroke, inženirstva in arhitekture. Pri prevodih se pojavlja poleg že omenjenih in uporabljenih slovenskih besednih zvez še problemsko orientiran pouk in problemsko naravnan ali zasnovan študij, kar nakazuje, da je veliko prispevkov s področja visokošolskega izobraževanja. Odstotki tako najdenih prispevkov v Cobiss prek slovenskih besednih zvez, navedenih v Preglednici 3, kot prispevkov, najdenih z angleško besedno zvezo, po kateri se imenuje kratica učnega pristopa, so zbrani na Sliki 3. 


\section{Iskanje IBL in PBL prispevkov v brskalniku COBISS}

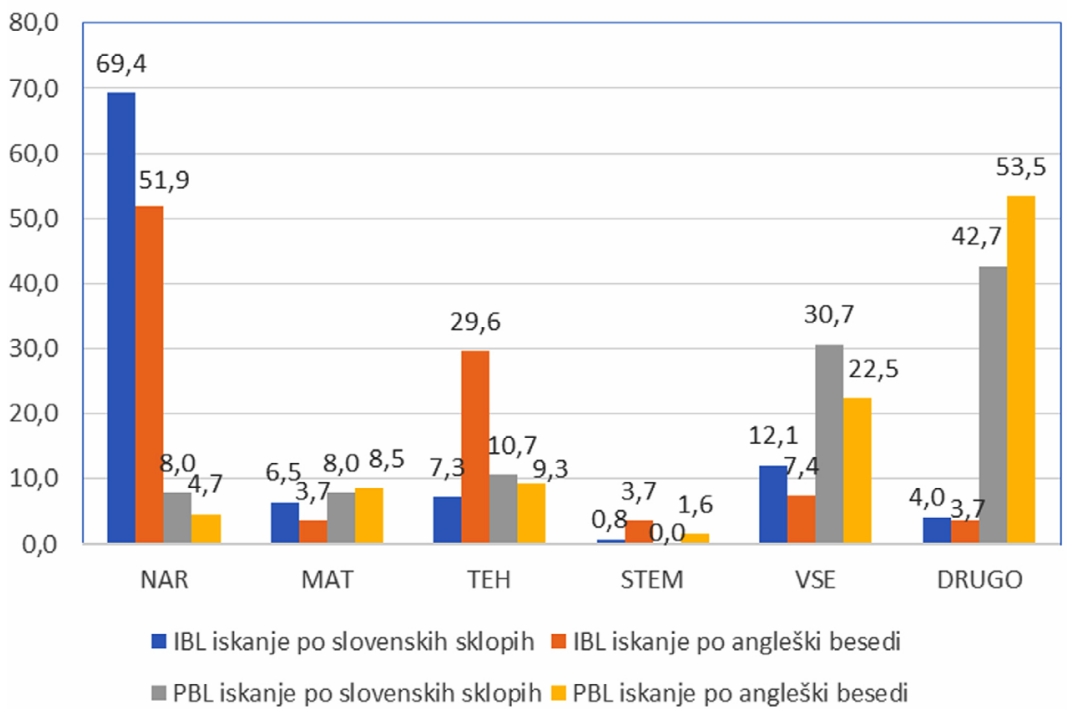

Slika I: Deležzi obravnavanih podrocíj prispevkov v brskalniku Cobiss, najdeni po eni izmedv Pregledniciz podanih slovenskib kluinnib besed za IBL oz.PBL, alipo angleški besedi inquiry based za IBL in problem based za $P B L$.

Odstotki področij, ki jih najdemo po tujih besednih zvezah, so podobni kot odstotki področij tistih prispevkov, ki jih najdemo s slovenskimi besednimi zvezami v Preglednici 3; področje STEM, ki združuje matematiko, naravoslovje, tehniko oz. tehnologijo kot strokovna področja (ali inženirstvo), je malo zastopano. Največja razlika je pri tehniki oz. tehnologiji, ki je zastopana v dobrih $7 \%$ prispevkov, najdenih s slovenskimi besednimi zvezami, in v slabih $30 \%$ prispevkov, najdenih po tuji besedni zvezi. Naravoslovja je največ pri IBL, druga področja so obakrat najbolj zastopana pri PBL. Po $8 \%$ je matematike pri PBL in do dvakrat manj pri IBL. Slika I z odstotki pa ne pokaže, da smo pri iskanju po slovenskih besednih zvezah našli veliko več prispevkov s področja IBL kot PBL, po tuji besedni zvezi pa je izid ravno obraten: PBL je zastopan v veliko večji meri kot IBL. Ker mnogo prispevkov nima dostopa do polnega besedila, smo vsebinsko analizo opravili pri tuji literaturi.

\section{Pregled prispevkov v tuji literaturi}

$\mathrm{V}$ iskalnik Springerlink s prispevki revije IJSME smo vstavili najprej besedno zvezo inquiry-based in nato zvezo problem-based (z vezajem ali brez). Od leta 2003 , ko je revija začela objavljati prispevke na spletu, do začetka 
leta 2018, ko smo pričeli z našo analizo, smo dobili 176 zadetkov za inquiry-based in 82 zadetkov za problem-based. Tako smo zadetke razdelili po petletnih obdobjih, da bi dognali trend obravnavanih pristopov. Poleg vezne besede -based se v praksi omenja tudi -oriented, -centred in morda še kaj drugega, vendar smo se pri analizi literature omejili le na -based, saj je to tudi osnova za kratici IBL in PBL. Najprej smo izločili prispevke, v katerih so besedne zveze slučajno skupaj, $\mathrm{v}$ katerih zveza ne pomeni učnega pristopa ali so besede najdene v literaturi. Izločili smo 30 zadetkov pri IBL in 34 zadetkov pri PBL. Preostalim zadetkom smo določili, kako poglobljeno v prispevku preučujejo učni pristop, kjer smo ločili prispevke

- neosrednje obravnave, ki pristop omenjajo v pozitivnem ali negativnem kontekstu, vendar ta ni osrednja tema prispevka, inovacija ni vključena v raziskovalna vprašanja;

- $\quad$ osrednje obravnave, kjer je dani pristop osrednja tema $v$ prispevku in vključen v raziskovalna vprašanja;

- $\quad$ in določili, pri katerem predmetu pristop preučujejo, kjer smo ločili

- matematiko,

- naravoslovje,

- matematiko in naravoslovje skupaj,

- STEM.

Prispevke smo razvrstili v petletna obdobja od začetka 2003 do začetka 2008 , od 2008 do začetka 2013 in od 2013 do začetka 2018 . Nato smo analizirali prispevke, kjer je dani pristop IBL ali PBL v središču obravnave, in jih karakterizirali glede področja učenja, nivoja poučevanja, kvalitete študije in preučevanih udeležencev raziskave.

\section{Primerjava upeljave IBL in PBL po petletnih obdobjih}

Besedna zveza inquiry-based se $\mathrm{v}$ prispevkih najpogosteje navezuje na learning, kar določa kratico IBL, pa tudi na education, strategy, approach, activities, instruction, science, project, practical work, teaching, classroom, course, method, lessons, experience, pedagogy. $\mathrm{V}$ po enem članku navajajo inquiry-based curriculum, interactions, investigastons ter mathematics in classical mechanics. Med prispevki, ki se sklicujejo na inquiry-based učni pristop $(n=146)$ tega bomo v nadaljevanju imenovali IBL-, se v kar 55,5 $\%$ prispevkov avtorji sklicujejo na ta pristop, a ta ni osrednja tema obravnave. IBL je večinoma omenjen $\mathrm{v}$ pozitivnem smislu kot pristop, $\mathrm{v}$ katerem je tema njihove raziskave (lahko) uspešna oziroma izpeljana, ali v zaključ$\mathrm{ku}$, da je njihova tematika primerna za IBL ali v skladu z IBL priporočili. V člankih, kjer omenjajo IBL, je v negativnem smislu IBL naveden le dvakrat, in sicer, da lahko aktivnosti, kot je IBL, če niso dobro vpeljane, 
privedejo do zmotnih prepričanj in da je v primeru, če IBL ne izvaja izkušeni učitelj, taka vpeljava zanj velik izziv. Seveda so v člankih, kjer je dani pristop osrednja tema obravnave, omenjene tudi nekatere kritike ali opozorila (Drobnič Vidic, 20I9). Od I 46 prispevkov se IBL pristop v II,o \% obravnava pri matematiki, v I3,0 \% pri matematiki in naravoslovju skupaj, le v 3,4 \% pri STEM predmetih in v 72,6 \% pri naravoslovju.

V 52 člankih najdemo besedno zvezo problem-based, ki se najpogosteje navezuje na learning, redkeje na approach in po enkrat na education, strategies, activities, scenario math teaching, assessments. Vsi se nanašajo na učni pristop, ki ga poimenujemo $\mathrm{PBL}$, le en prispevek uporablja kratico PBL s poimenovanjem project-based learning. Kar 84,6 \% prispevkov se sklicuje na ta pristop, a ta ni osrednja tema obravnave, prispevkov s pristopom kot osrednjo temo obravnave je le $15,4 \%$. Večinoma je PBL omenjen $\mathrm{v}$ pozitivnem smislu ali nevtralno kot konstruktivistično učenje, kjer je promovirano kritično razmišljanje, omogočeno samoregulacijsko učenje ali učenje, imenovano science writing heuristics, ki vključuje tako segmente IBL kot PBL. V negativnem smislu je PBL uporabljen v prispevkih le dvakrat, prvič omenjajo, da pri PBL študenti izkazujejo nižje osnovno znanje $\mathrm{v}$ medicini od tistih pri tradicionalnem pouku in da je PBL eden od na učenca osredotočenih učnih pristopov, kjer pri eksperimentalnem preučevanju nastopi mnogo nekonsistentnosti primerjalnih skupin. Med 52 prispevki je 19,2 \% prispevkov na področju matematike, II,6 \% na področju matematike in naravoslovja skupaj, le 9,6 \% pri STEM predmetih in 59,6 $\%$ na področju naravoslovja.

Oba pristopa imata največ obravnav na področju naravoslovja, vendar je pri IBL razmerje prispevkov iz naravoslovja in matematike $65: 10$, pri PBL pa 30 : 10. Pri PBL je večji delež matematike in področja STEM kot pri IBL, kjer je večji delež naravoslovja ter matematike in naravoslovja skupaj. Pri IBL je precej večji delež prispevkov, kjer je pristop osrednja tema obravnave, kot pri PBL, kjer je takih prispevkov malo.

Prispevke smo nato razdelili na petletna obdobja, da bi videli, kako se vrednosti spreminjajo po letih. Primerjava vrednosti po petletnih obdobjih na Sliki 2 kaže, da deleži prispevkov, kjer je učni pristop v osrednja tema obravnave, skorajda linearno naraščajo (prekinjeni črti). Polni črti na Sliki 2 nakazujeta, da število prispevkov o IBL kot neosrednji obravnavi v drugem petletnem obdobju upade, v zadnjem strmo naraste, pri PBL pa prispevki z neosrednjo obravnavo dokaj linearno naraščajo. 


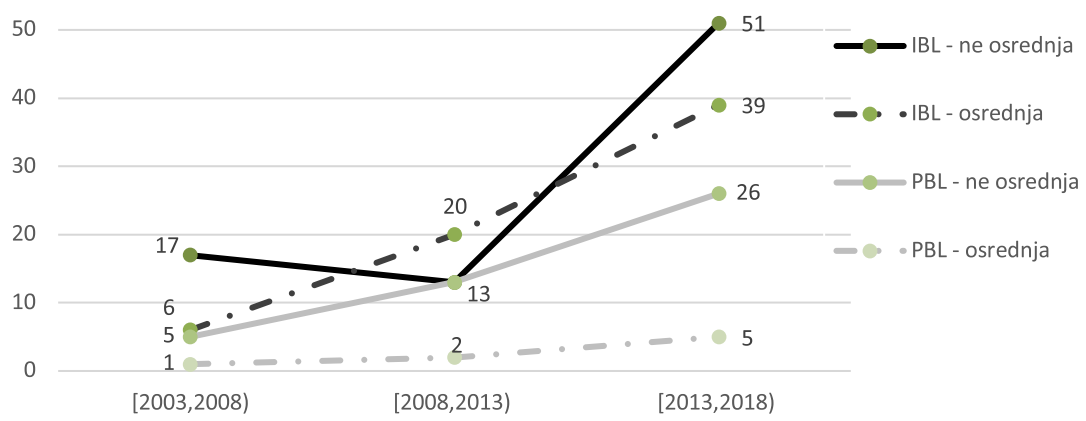

Slika 2. Trend osrednjih in neosrednjih obravnav po stevilu prispevkov v IJSME zIBL inlali PBL.

Področja IBL in PBL prispevkov po 5-letnih obdobjih

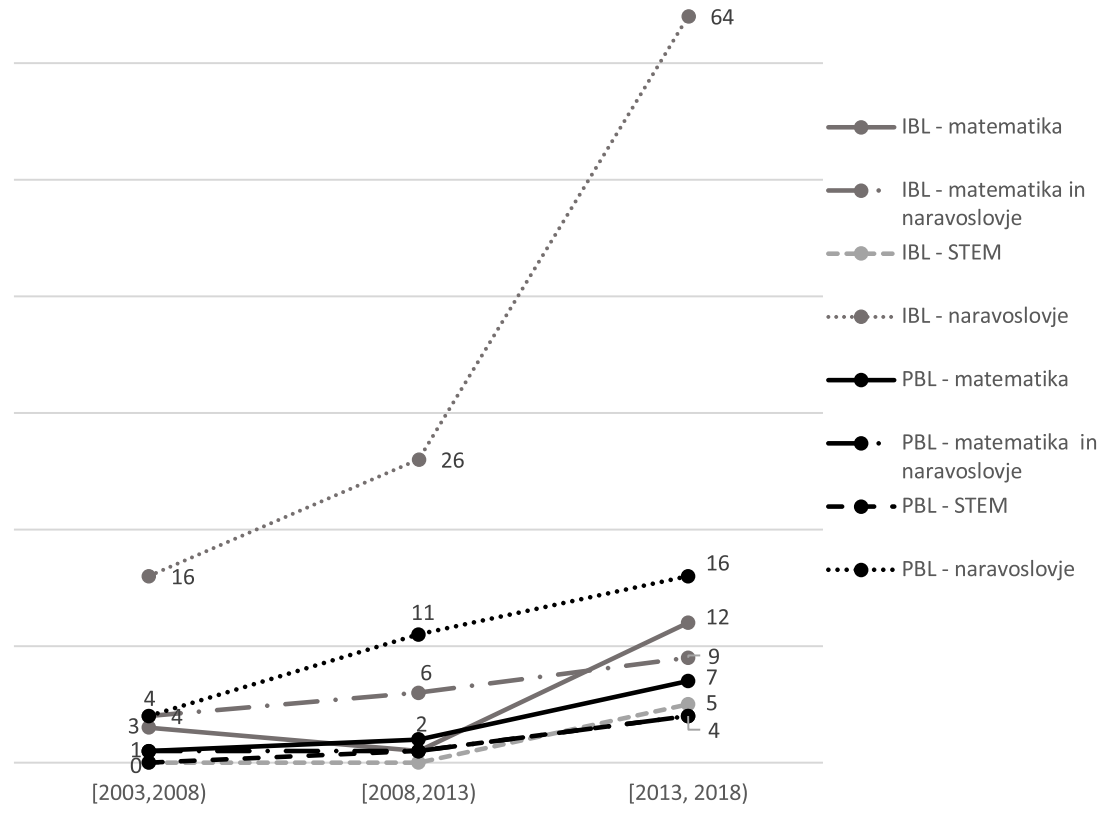

Slika 3. Trend IBL in PBL objav po stevilu prispevkov v IJSME po področjih: samo matematika, samo naravoslovje, matematika in naravoslovje skupaj, STEM: matematika, naravoslovje, tehnika/tehnologija, inženirstvo (strokouni predmeti) skupaj. 
Število prispevkov o IBL oziroma PBL po posameznih področjih z leti narašča, kot kaže Slika 3 , razen področja matematike pri IBL, kjer število prispevkov $\mathrm{v}$ drugem petletnem obdobju pade $s 3$ na I, potem pa naraste na I2 prispevkov v zadnjem petletnem obdobju. Povezovanje STEM predmetov z IBL ali PBL je trend zadnjega petletnega obdobja, a še to z malo prispevki (črtkani črti na Sliki 3). Najmanj hitro naraščajo prispevki z matematiko in naravoslovjem skupaj (črtkano-pikčasta črta na sliki), najhitreje pa naraščajo prispevki o IBL s področja naravoslovja, kjer je tudi daleč največ prispevkov, v zadnjem petletnem obdobju kar 64 .

\section{Analiza prispevkov, kjer je IBL ali PBL osrednja tema obravnave}

Prispevke iz IJSME, kjer je IBL ali PBL osrednja tema obravnave, smo analizirali podrobneje. Pri vsakem prispevku smo ugotovili, na katerem področju učenja je dani pristop raziskan, na kateri stopnji izobraževanja, kakšna vrsta raziskave je izvedena in katera metoda raziskovanja je izpostavljena, delne izsledke smo predstavili v Drobnič Vidic, 2019. Nazadnje smo ugotovili, ali so udeleženci v raziskavi učenci, učitelji ali morda oboji.

Od skupno 73 raziskav, kjer je eden od preučevanih pristopov v središču obravnave, je matematika zastopana $\mathrm{v}$ štirih prispevkih, naravoslovje pa v 56 prispevkih, kar kaže Preglednica 4. Iz nje razberemo, da več kot polovica raziskav zajema osnovnošolski nivo izobraževanja, kvantitativne in kvalitativne raziskave so dokaj enakomerno zastopane, najpogosteje pa se avtorji poslužujejo kavzalno-neekperimentalne metode, le en prispevek pa uporablja več metod raziskovanja. Zanimivo je, da so v več kot polovici raziskav kot preučevane osebe zastopani učitelji ali prihodnji učitelji.

Čeprav je prispevkov IBL učnega pristopa veliko več kot pristopa PBL, napravimo primerjavo med pristopoma. Naravoslovje je v obeh učnih pristopih raziskano $\mathrm{v}$ veliko večji meri kot matematika, ki pri PBL sploh ni zastopana, pri IBL pa je delež matematike le $6,2 \%$ (Preglednica 4). Prav tako preglednica kaže, da sta matematika in naravoslovje kot skupno področje zastopana le pri IBL (I2,3 \%), pri PBL pa je dobro zastopano STEM področje ( $25 \%$ ). Glede nivoja izobraževanja je pri IBL izpostavljen osnovnošolski nivo $\mathrm{v}$ več kot polovici prispevkov, univerzitetni pa le v $18,7 \%$, medtem ko so nivoji pri PBL dokaj enakomerno porazdeljeni. Kvantitativne in kvalitativne raziskave so enakomerno zastopane pri IBL, pri PBL je več kvalitativnih raziskav. Pri obeh pristopih prevladuje kavzalno-neeksperimentalna metoda, ki najpogosteje vključuje študijo primera. Pri PBL so najpogostejši akterji v raziskavi učenci $(62,5 \%)$, pri IBL pa učitelji ali prihodnji učitelji, ki so preučevani v $55,4 \%$ prispevkov. 
Preglednica 4: Karakteristike osrednjih objav o IBL ali PBL.

\begin{tabular}{|c|c|c|c|c|c|c|}
\hline Preučevana inovacija: & IBL & $\%$ & PBL & $\%$ & Skupaj & $\%$ \\
\hline Področje preučevanja & 65 & I00,०\% & 8 & I0०,०\% & 73 & $100,0 \%$ \\
\hline Matematika & 4 & $6,2 \%$ & $\circ$ & ०,०\% & 4 & $5,5 \%$ \\
\hline Matematika in naravoslovje & 8 & $12,3 \%$ & $\circ$ & ०,०\% & 8 & $11, O \%$ \\
\hline STEM & 3 & $4,6 \%$ & 2 & $25,0 \%$ & 5 & $6,8 \%$ \\
\hline Naravoslovje & 50 & $76,9 \%$ & 6 & $75,0 \%$ & 56 & $76,7 \%$ \\
\hline Nivo izobraževanja & 65 & $100,0 \%$ & 8 & IO०,०\% & 73 & I00,0\% \\
\hline Osnovna šola & 38 & $58,5 \%$ & 3 & $37,5 \%$ & 42 & $57,5 \%$ \\
\hline Srednja šola & 15 & $23,1 \%$ & 3 & $37,5 \%$ & 18 & $24,7 \%$ \\
\hline Univerza in več & $\mathrm{I} 2$ & $18,4 \%$ & 2 & $25,0 \%$ & $\mathrm{I} 3$ & $17,8 \%$ \\
\hline Vrsta raziskave & 65 & $100,0 \%$ & 8 & $100,0 \%$ & 73 & $100,0 \%$ \\
\hline Kvantitativna & 27 & $41,5 \%$ & 3 & $37,5 \%$ & 30 & $4 \mathrm{I}, \mathrm{I} \%$ \\
\hline Kvalitativna & 27 & $41,5 \%$ & 5 & $62,5 \%$ & 32 & $43,8 \%$ \\
\hline Mix & II & $16,9 \%$ & ○ & ০,०\% & II & $15,1 \%$ \\
\hline Raziskovalna metoda & 65 & $100,0 \%$ & 8 & $100,0 \%$ & 73 & IO०,०\% \\
\hline Kavzalno-eksperimentalna & 16 & $24,6 \%$ & I & $12,5 \%$ & 17 & $23,3 \%$ \\
\hline Kvazi kavzalno-eksperimentalna & 9 & $13,8 \%$ & I & $\mathrm{I} 2,5 \%$ & 10 & $13,7 \%$ \\
\hline Kavzalno-neeksperimentalna & 38 & $58,5 \%$ & 6 & $75,0 \%$ & 44 & $60,3 \%$ \\
\hline Deskriptivna & I & $1,5 \%$ & $\circ$ & ०,०\% & I & $\mathrm{I}, 4 \%$ \\
\hline Nedoločeno & I & $1,5 \%$ & ० & ०,०\% & I & $\mathrm{I}, 4 \%$ \\
\hline Osebe preučevanja & 65 & IO०,०\% & 8 & $100,0 \%$ & 73 & $100,0 \%$ \\
\hline Učenci & $2 \mathrm{I}$ & $32,3 \%$ & 5 & $62,5 \%$ & 26 & $35,6 \%$ \\
\hline Učitelji ali prihodnji učitelji & 36 & $55,4 \%$ & 2 & $25,0 \%$ & 38 & $52,0 \%$ \\
\hline Učenci in učitelji & 7 & $\mathrm{IO}, 8 \%$ & I & $12,5 \%$ & 8 & $11,0 \%$ \\
\hline Drugo & I & $1,5 \%$ & $\circ$ & ০,०\% & I & $\mathrm{I}, 4 \%$ \\
\hline
\end{tabular}

Podrobnejša analiza prispevkov, povezanih z matematiko

Kljub obetavnemu številu IBL raziskav (65), kjer je učni pristop v središču preučevanja, ugotovimo, da ni veliko takih prispevkov, ki so povezani z matematiko. $Z$ njo je povezanih is prispevkov, ki jih bomo podrobneje analizirali: $4 \mathrm{~s}$ področja matematike, $8 \mathrm{~s}$ področja matematike in naravoslovja skupaj ter tri s področja STEM, kjer se predmetoma pridruži 
še tehnika / tehnologija in inženirstvo (oziroma strokovni predmeti). V Preglednici 5 so razvrščeni po letu objave, kjer prvi prispevek sodi v prvo petletno obdobje (Rogers et al., 2007), naslednji štirje pa v drugo petletno obdobje. Preučili bomo še 2 prispevka, ki imata v središču obravnave pristop PBL pri STEM predmetih.

Med IBL prispevki je $\mathrm{v}$ več kot polovici obravnavan osnovnošolski nivo matematike (v kombinaciji z naravoslovjem ali STEM predmeti), preostanek si dokaj enakomerno delita srednješolski in univerzitetni nivo, kar kaže Preglednica 5. Od prispevkov, ki smo jim dodelili osnovnošolski nivo izobraževanja, pa jih kar 5 sega še v srednješolski nivo. Dalje je med prispevki največ kvantitativnih raziskav, le 4 raziskave so namreč kvalitativne in 2 mešani. Samo v eni uporabijo kavzalno-eksperimentalno metodo (Dogan, 2012) in pri dveh kvazi kavzalno-eksperimentalno metodo, kjer preučujejo učinek eksperimentalnega faktorja s testom pred in po njem. Pri enajstih raziskavah uporabijo kavzalno-neeksperimentalno metodo, od tega je 5 študij primera in 6 analiz vprašalnika, v eni raziskavi pa avtorji uporabijo opisno metodo. Kar 9 prispevkov je takih, kjer so osebe učitelji ali prihodnji učitelji, nato so trije prispevki, kjer so preučevane osebe učenci in enako število raziskav učiteljev in učencev skupaj. Prispevki so podrobneje opisani v Preglednici 5.

Od osmih prispevkov s področja matematike in naravoslovja skupaj le en prispevek interdisciplinarno vključuje obe področji v pouk (Wing Mui, 2013), pri enem preučujejo mnenja učiteljev obeh predmetov o smiselnosti in pogostosti vključevanja IBL v pouk (Marshall et al., 2009), pri ostalih prispevkih pa razvijajo vprašalnik (Marshall et al., 2010; Shore et al., 20I2) ali izobražujejo učitelje na obeh področjih skupaj, a ni nujno, da snov pri IBL tudi interdisciplinarno povezujejo (Lotter et al., 20r4; Rogers et al., 2007; Tuan et al., 2017; Turner et al., 2018). Osebe v raziskavi so vselej učitelji ali prihodnji učitelji, dvakrat ti skupaj z učenci.

Pri treh STEM področjih matematika med predmeti nikjer ni posebej izpostavljena. V raziskavi (Ibrahim et al., 2017) z MAVIES vprašalnikom ugotavljajo, v kolikšni meri se vključuje v STEM projekte matematično razmišljanje, obliko interdisciplinarne povezanosti STEM predmetov in delež samostojnega raziskovanja pri študiju na splošno. Thibaut in sodelavci (2019) preučujejo pomen osebnega prepričanja za izvedbo interdisciplinarnega povezovanja STEM predmetov z IBL ali PBL na belgijskih srednjih šolah, ena raziskava pa je opisna primerjava treh šol s PBL ali IBL STEM doktrino brez konkretnih interdisciplinarnih povezav (Lesseig et al., 2019).

Med štirimi prispevki iz samostojnega področja matematika s pristopom IBL so kar trije, ki vsebujejo konkretne primere srednješolskih 
Preglednica s: Prispevki o IBL v IJSME na področju matematike (skupaj z drugimi predmeti).

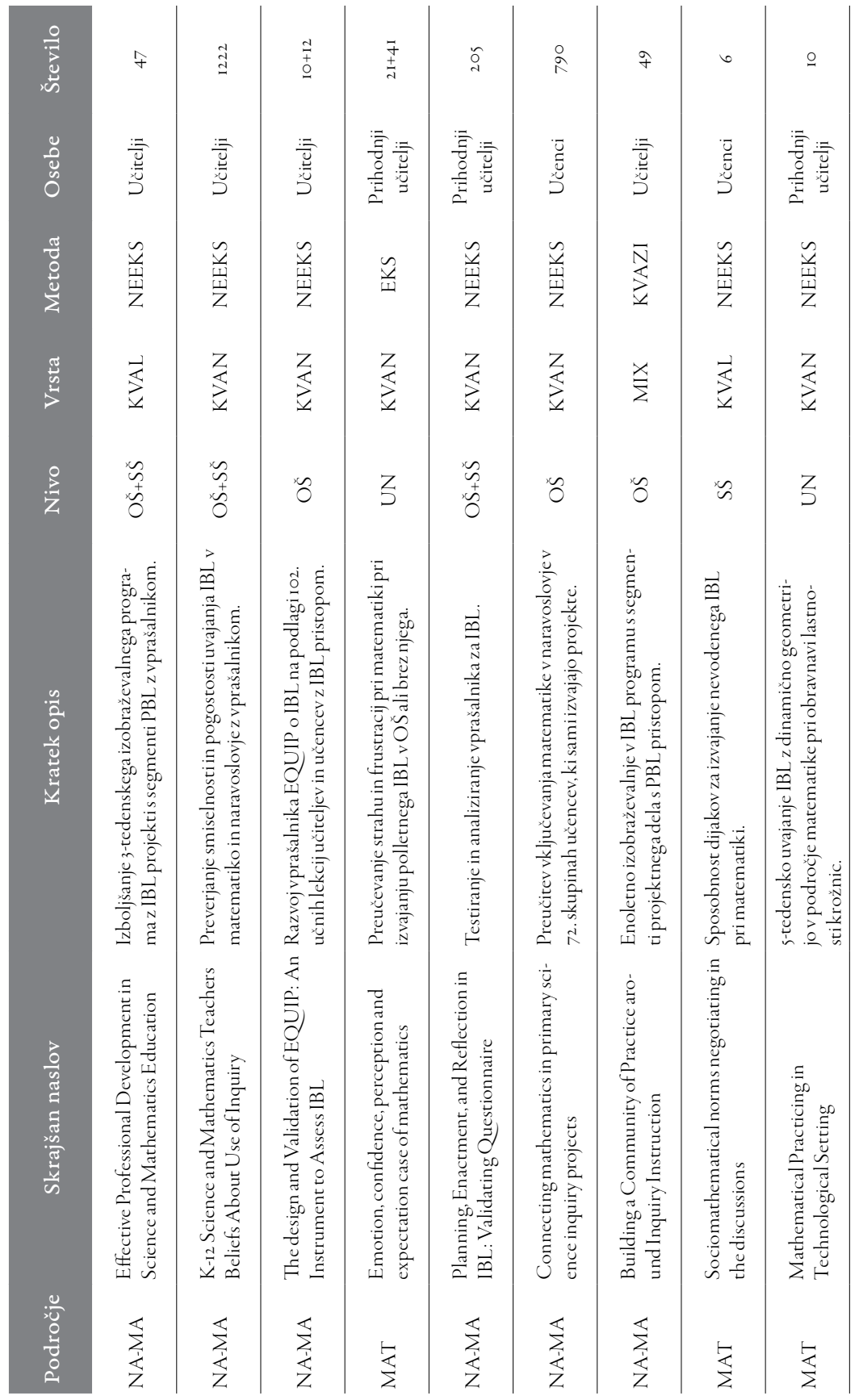




\begin{tabular}{|c|c|c|c|c|c|c|}
\hline 胥 & ส & $\check{\infty}$ & $\tilde{\infty}$ & 4 & $\tilde{\text { dे }}$ & $\gamma$ \\
\hline $\begin{array}{l}\text { गे } \\
\text { ठू. } \\
0\end{array}$ & 竞 & 捣 & 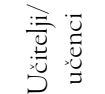 & 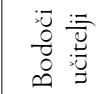 & 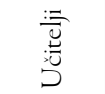 & 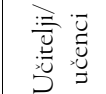 \\
\hline $\begin{array}{l}\frac{\pi}{0} \\
\stackrel{0}{0} \\
\stackrel{0}{\Sigma}\end{array}$ & $\underset{\Sigma}{\mathbb{2}}$ & $\begin{array}{l}\frac{y}{y} \\
\frac{1}{Z}\end{array}$ & $\begin{array}{l}\tilde{y} \\
\frac{w}{4} \\
Z\end{array}$ & $\begin{array}{l}\tilde{y} \\
\underline{\underline{H}} \\
\text { Z }\end{array}$ & $\begin{array}{l}\tilde{y} \\
\frac{w}{4}\end{array}$ & $\begin{array}{l}\frac{a}{v} \\
\frac{\omega}{b} \\
0\end{array}$ \\
\hline $\begin{array}{l}\mathbb{5} \\
\stackrel{5}{5}\end{array}$ & $\stackrel{x}{\vec{z}}$ & $\underset{z}{z}$ & $\underset{z}{Z}$ & $\underset{\Sigma}{\frac{1}{2}}$ & $\underset{z}{Z}$ & $\underset{z}{\stackrel{2}{2}}$ \\
\hline$\stackrel{\circ}{\stackrel{8}{Z}}$ & $\approx$ & Z & $\begin{array}{c}\tilde{n} \\
\tilde{n} \\
0\end{array}$ & $\approx$ & $\approx$ & $\begin{array}{l}\tilde{n} \\
\tilde{n} \\
0\end{array}$ \\
\hline 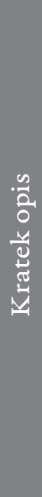 & 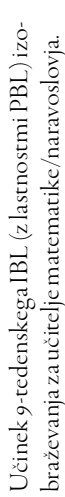 & 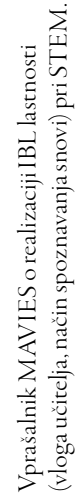 & 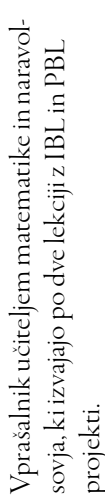 & 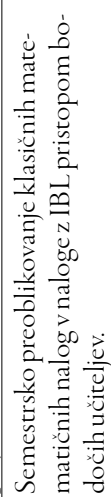 & 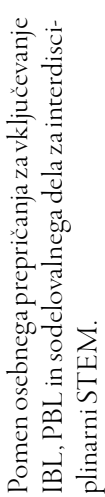 & 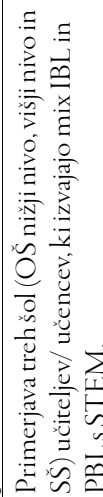 \\
\hline 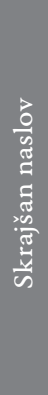 & 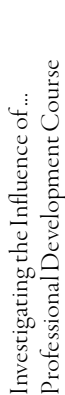 & 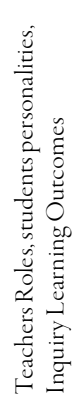 & 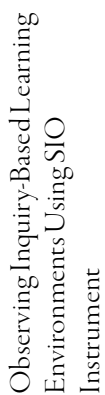 & 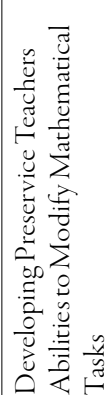 & 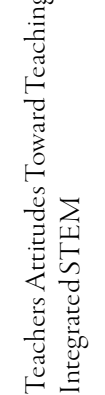 & 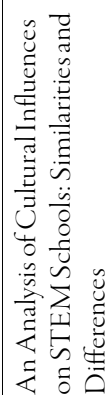 \\
\hline 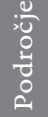 & 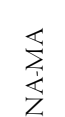 & $\underset{⿱ 乛 龰}{\mid}$ & 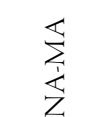 & 战 & $\underset{⿱ 乛 龰}{\sum_{n}}$ & $\overrightarrow{5}$ \\
\hline
\end{tabular}


nalog iz geometrijske snovi o krožnicah (Akyuz, 2016), iz snovi o limitah in odvodih (Partanen in Kaasila, 2015) in iz različnih učnih snovi od statistike do geometrije in funkcij (Lee et al., 2019). V slednjem prispevku ugotavljajo sposobnost prihodnjih učiteljev za preoblikovanje klasičnih na$\log$ iz učbenikov v naloge za izvedbo IBL in podajo smernice za izboljšanje izobraževalnih programov na tem področju. Partanen in Kaasila (2015) preučujeta raziskovanje socioloških matematičnih norm pri raziskovanem učenju IBL dveh majhnih skupin dijakov, medtem ko Akyuz (2016) preučuje sposobnosti raziskovalnega učenja $\mathrm{z}$ dinamično geometrijo prihodnjih učiteljev matematike. Četrti prispevek je edini z eksperimentalno metodo eksperimentalne in kontrolne skupine, kjer preučujejo strah in frustracije pri matematiki z IBL in brez njega pri prihodnjih učiteljih matematike (Dogan, 20I2).

Kot smo v prejšnjem razdelku pri analizi prispevkov z osrednjo temo IBL pristopa ugotovili, da so preučevane osebe najpogosteje učitelji in prihodnji učitelji, tudi konkretni primeri prispevkov, povezanih z matematiko v tem razdelku, kažejo, da je v tujini tendenca pripraviti učitelje na IBL in pripraviti instrumente za merjenje njegove učinkovitosti. Veliko prispevkov povezuje s pristopoma učitelje matematike in naravoslovja, redko pa interdisciplinarno povezujejo obe področji. V analizi raziskav smo opazili, da sta IBL in PBL pogosto povezana, saj se v petnajstih raziskavah, povezanih z matematiko, pri šestih omenja PBL skupaj z IBL (Lesseig et al., 2019; Lotter et al., 2014; Rogers et al., 2007; Thibaut et al., 2019; Tuan et al., 2017; Turner et al., 2018).

Imamo le 2 prispevka, kjer je PBL osrednja tema obravnave in je področje povezano $\mathrm{z}$ matematiko. Ta dva prispevka preučujeta področje STEM. Enega smo omenili že pri IBL, je edina opisna analiza s primerjavo treh šol z IBL ali PBL izvedbo pri STEM predmetih (Lesseig st al., 2019). V drugem prispevku preučujejo PBL učni pristop, ki ga imenujejo project-based learning, vendar se $\mathrm{v}$ njem srednješolci ukvarjajo $\mathrm{z}$ nestrukturiranimi problemi kot pri PBL (Han et al., 2015). Avtorji s kvantitativno kavzalno-eksperimentalno metodo primerjajo, kako tako učenje vpliva na boljše in slabše učence pri STEM predmetih.

Če vrednosti v Preglednici 5, navedene v tem razdelku, preračunamo $\mathrm{v}$ odstotke, ugotovimo, da so ti v vseh kategorijah zelo podobni odstotkom v zadnjem stolpcu Preglednice 4, ki kaže karakteristike prispevkov vseh področij v IJSME, tako matematike kot naravoslovja, večja razlika je le v količini kvantitativnih raziskav. Teh je skupno 4I,I \% (Preglednica 4), pri prispevkih povezanih z matematiko, pa jih je 9, kar je v deležu 62,5\%, sorazmerno manj pa je kvalitativnih raziskav. 
Zanimivo je, da od vseh teh prispevkov IBL ali PBL pristopov, povezanih $s$ področjem matematike, le $s$ prispevkov najdemo $\mathrm{z}$ iskalnikom Wos s ključnimi besedami problem-based, inquiry-based in mathematics, kjer smo opravili iskanje z namenom nadaljnjega preučevanja te tematike, čeprav iskalnik vključuje raznovrstne visokokakovostne revije $s$ faktorjem vpliva, torej tudi revijo IJSME. Vzrok je nepojavljanje iskanih besed $\mathrm{v}$ povzetku, naslovu ali ključnih besedah, ki jih iskalnik preičče, lahko tudi drugačno poimenovanje omenjenih učnih pristopov, enkrat tudi iskana beseda, ki se ne pojavi v osnovni zapisani obliki, ali pa je vzrok novejši članek, saj na Wos pridejo prispevki z več kot enoletnim zamikom, mi pa smo obravnavali prispevke IJSME prek brskalnika SpringerLink takoj, ko so prišli na splet (še pred tiskano objavo).

\section{Interpretacija rezultatov}

Podatki prispevkov iz slovenske virtualne knjižnice kažejo, da se na Slovenskem ukvarjamo z IBL in PBL v 21. stoletju, saj je pred letom 2000 objavljenih le in prispevkov s področja IBL ali PBL od 199. Kratko lahko strnemo, da IBL v slovenski literaturi prevladuje $\mathrm{z}$ imenom raziskovalno učenje oziroma učenje $\mathrm{z}$ raziskovanjem $\mathrm{v}$ naravoslovju in ima $\mathrm{v}$ polovici primerov prevod inquiry-based learning, $\mathrm{v}$ polovici primerov drugačnega, a je pogosto brez angleškega prevoda. PBL prevladuje z imenom problemsko (naravnano) učenje na drugih področjih, kot so medicina in tuj jezik stroke $s$ prevladujočim prevodom problem-based learning $\mathrm{v}$ tujejezičnih prispevkih. $V$ poimenovanjih učnih pristopov pa smo neenotni, saj uporabljamo tudi izraze preiskovalno učenje na področju matematike ali poizvedovalno učenje na področju tehnike oz. tehnologije in druge izraze za PBL, a nekoliko redkeje.

Medtem ko je v slovenskem brskalniku IBL pristop večinoma vezan na področje naravoslovja, je pristop PBL vezan na druga področja. Pri matematiki je procentualno PBL malo bolje zastopan kot IBL. Pri tehniki oz. tehnologiji se kaže največja razlika med številom objav za IBL najdenih prek slovenskih besednih zvez in objav, najdenih po angleški besedi. Razmerje med slovenskimi in tujejezičnimi prispevki je pri IBL okoli Io proti 2 v korist slovenskih prispevkov, pri PBL pa je tujejezičnih prispevkov malo manj kot polovica. To morda nakazuje, da prispevki o PBL segajo v terciarno področje, ki je veliko bolj vpeto $\mathrm{v}$ tuj izobraževalni prostor kot ostala področja.

$\mathrm{Z}$ nekoliko neobičajno študijo literature smo pridobili vpogled $v$ uvajanje IBL in PBL na področje matematike na tujem. Osredotočili smo se na revijo, ki enakovredno objavlja prispevke s celotnim besedilom na področju izobraževanja matematike in naravoslovja, pri kateri smo 
ugotavljali zastopanost posameznega pristopa na področju matematike glede na naravoslovje. Prispevke z IBL in PBL pristopom smo ločili po petletnih obdobjih. Oba učna pristopa se pogosto omenjata kot primera dobre prakse na področju matematike in na področju naravoslovja, toda člankov, ki imajo PBL kot osrednjo temo obravnave, je veliko manj kot tistih z IBL. Učna pristopa sta v naravoslovju pogosteje zastopana kot v matematiki, a se v odstotkih matematika nekoliko bolj pogosto omenja pri PBL kot pri IBL (ne pa tudi poglobljeno obravnava). Lahko rečemo, da se na področju matematike pristop PBL omenja pogosteje kot IBL, vendar je potem manj konkretnih realizacij. To niti ne preseneča, saj je PBL pristop precej bolj zahteven tako s stališča zahtev, kot s stališča učiteljevih priprav in aktivnosti učencev. Naraščanje števila prispevkov po petletnih obdobjih, ki ima enega od obravnavanih pristopov za osrednjo temo obravnave, nakazuje, da sta pristopa obetavna na vseh obravnavanih področjih, najbolj pa to velja za IBL na področju naravoslovja. Prav tako je trend zadnjega petletnega obdobja vpeljava enega od pristopov interdisciplinarno na področje STEM.

Pregled prispevkov, ki imajo IBL ali PBL kot osrednjo temo obravnave, se sklada s teoretičnimi izhodišči, da se IBL najpogosteje omenja na področju naravoslovja, vpeljava tja je precej bolj pogosta kot v matematiko (podobno smo ugotovili tudi s slovenskim pregledom). Prav tako je število prispevkov skladno s teoretičnimi karakteristikami, da se IBL najpogosteje obravnava na osnovnošolskem nivoju, pri PBL pa univerzitetni nivo sicer ni najbolj zastopan, kot navajajo teoretični izsledki, a enakovredno nastopa z ostalima nivojema. Analiza tudi nakazuje, da so pri IBL vrste raziskav enakomerno zastopane, pri PBL prevladuje kvalitativna statistična analiza. Morda temu botruje težavno eksperimentalno primerjanje PBL s tradicionalnim poukom, kar smo prebrali kot negativno kritiko v enem izmed IJSME prispevkov. Pri obeh pristopih pa je malo eksperimentalnih raziskav v primerjavi z neeksperimentalnimi. Pri IBL so najpogostejše osebe v raziskavi učitelji ali prihodnji učitelji, pri PBL pa učenci. To nakazuje, da se pri IBL bolj osredotočajo na učiteljeve priprave na drugačno izvedbo pouka kot pri PBL, kjer so učitelji pogosto samouki.

Podrobnejša analiza tistih prispevkov, ki segajo na področje matematike, ponovno nakazuje, da posvečajo raziskovalci pri IBL veliko pozornosti izobraževanju učiteljev in njihovi pripravi na drugačen pristop učenja in poučevanja. Učitelje in prihodnje učitelje matematike in naravoslovja izobražujejo v posebnih izobraževalnih programih za realizacijo IBL v pouk ali z njimi preverjajo instrumente za merjenje učinkovitosti IBL. Pri vključevanju IBL v STEM je matematika zaenkrat bolj v imenu kot $\mathrm{v}$ dejanski interdisciplinarni povezavi, pa tudi povezav matematike $\mathrm{z}$ 
naravoslovjem skorajda ni, saj gre le za skupne napore učiteljev enega in drugega področja za realizacijo IBL. Zanimivo pa je, da najdemo v tistih maloštevilnih prispevkih, ki IBL uvajajo v čisto matematiko, tudi konkretne primere problemov.

Skoraj polovica prispevkov, povezanih s področjem matematike, poleg IBL pristopa vključuje tudi karakteristike PBL pristopa ali omenja tudi ta pristop, kar ne nasprotuje teoretični domnevi, da je IBL krovni pristop in lahko vsebuje tudi PBL, kar najbrž tudi pripomore k večji zastopanosti krovnega pristopa v prispevkih (Preglednica 5).

\section{Zaključek}

Poimenovanje na pedagoškem področju v slovenskem jeziku je občutljiva dejavnost, saj področje združuje raziskovalce različnih strok in izobraževalnih nivojev, ki poimenovanja pogosto oblikujejo po lastnih zamislih. Prav zaradi neenotnosti poimenovanj in zahtevne slovenske slovnice pa je iskanje objav določenega učnega pristopa zahtevno, kar slovenske raziskovalce na pedagoškem področju bolj ločuje kot pa združuje. Že tako majhno slovensko jezikovno področje po našem mnenju ne potrebuje posebnega izrazoslovja učnega pristopa pri različnih predmetih. Na podlagi najdenih poimenovanj slovenske literature bi se odločili za enotno imenovanje raziskovalno (naravnano) učenje: $R N U$ za IBL ter problemsko (naravnano) učenje: PNU za PBL, kar pa bi moralo biti usklajeno in odobreno s strani strokovnjakov s področja didaktike. Beseda v oklepaju nakazuje, da je to učni pristop, ki se v kurikulum uvaja kontinuirano daljše časovno obdobje.

Izvedena raziskava slovenske in tuje literature ima precej omejitev, ki jih je treba izpostaviti. Prvič: zaradi izpostavljenega neenotnega poimenovanja pristopov učenja oz. poučevanja je nemogoče obravnavati vsa poimenovanja za omenjena pristopa in tako povedati, kolikšen del na temo navezujočih se prispevkov je sploh bil analiziran. Iskanja nismo usmerili na problemsko ali raziskovalno orientirano učenje oz. poučevanje na primer (ang. problem-oriented learning, inquiry-oriented learning), ki se tudi pojavlja pri nas in v svetu (prim. Rahayu et al., 20II; Woods, 20I4). Prav to smo v prispevku želeli tudi poudariti, saj bi enotno poimenovanje učitelju, ki želi neko inovacijo vpeljati v prakso, zelo olajšalo delo. Pri slovenski literaturi so poleg pestrega nabora poimenovanj še dodatne težave, saj vse slovenske objave niso vodene elektronsko. Pri pregledu tuje literature smo se omejili na pregled ene same visokokakovostne revije, in sicer IJSME, kar je tudi treba dodati med omejitve. Vendar pa menimo, da nam je uspelo s to selekcijo realno predstaviti delež objav obeh pristopov na področju matematike in naravoslovja. Ta omejitev področja na naravoslovje in 
matematiko je precej zmanjšala število zadetkov, saj je ta selekcija izločila mnoge prispevke, pri katerih bi bila lahko celovita slika splošne uporabe pristopov drugačna. Seveda pa to ni bil naš namen. Za vpogled v prispevke z enim od omenjenih učnih pristopov za področje matematike bi bilo smiselno v prihodnje analizirati prispevke celotne baze Wos ali Scopus, kjer bi dobili več zadetkov uporabe samo na področju matematike.

Ker je PBL s svojimi karakteristikami - delo v majhnih skupinah, spoznavanje nove snovi preko interdisciplinarnih problemov, samostojnost učencev pri iskanju novi informacij in učiteljeva vloga tutorja - težje izvedljiv kot IBL, je vsaj v fazi vpeljevanja v pouk matematike IBL enostavnejši, bolj prilagodljiv trenutnim zahtevam kurikuluma in prijaznejši učiteljem. Pri realizaciji obeh ne gre pozabiti, da to ni učna metoda, ki jo vpeljemo v pouk le enkrat $\mathrm{v}$ delu učne ure, ampak gre za dolgoročno tendenco učitelja, da neka nova situacija (pojav, problem, projekt) sproži pri pouku aktivnosti in razmišljanje učencev, ki na podlagi predznanja, radovednosti in učiteljeve podpore sprašujejo, odgovarjajo in pridejo do novih spoznanj na konstruktivistični način. Ko se želimo kot učitelji pripraviti na novo vlogo usmerjevalca pri IBL ali PBL, bomo našli veliko tuje literature o IBL, pri iskanju materiala za delo učencev pa nam pogosto pomagajo prispevki o PBL z realnimi problemi, saj ti pri pouku matematike pogosteje kot naravni pojavi oziroma situacije izzovejo matematične aktivnosti, kot je reševanje problemov.

Tako IBL kot PBL omogočata interdisciplinarno povezovanje matematike $\mathrm{z}$ drugimi predmeti, kar je priporočilo v naših učnih načrtih in kar smo zaznali kot trend zadnjega petletnega obdobja v tuji literaturi predvsem pri povezovanju STEM predmetov (Slika 3). Vsebinski pregled tuje visokokakovostne revije s področja matematičnega in naravoslovnega izobraževanja pa pokaže, da je manj prispevkov, ki bi prikazali dolgoročno realizacijo pristopa na interdisciplinarnem področju matematike in naravoslovja s konkretnim materialom (naloge, problemi), več je analiz razvoja instrumentov za merjenje učinkovitosti pristopa in splošnih izobraževalnih programov za učitelje, kar je zaslediti v zadnjih letih tudi pri povezovanju STEM predmetov. Specifični pregled literature nam tudi kaže, da imamo učitelji pri iskanju kvalitetnih prispevkov, ki bi nam pomagali pri lastni vpeljavi pristopa, težave. Mnogi kvalitetni prispevki v ključnih besedah, naslovu ali povzetku nimajo zapisanega imena za dani pristop oziroma poimenujejo pristop drugače kot večina raziskovalcev (Wing Mui, 2013) ali nimajo zapisane iskane besede v pravi slovnični obliki (Partanen in Kaasila, 2015), zato taki prispevki z običajnim iskanjem ne dosežejo ciljne populacije. Prav zato moramo tudi v slovenskem jeziku skrbno izbirati 
A. DROBNIČ VIDIC • PRIMERJAVA DVEH INTERDISCIPLINARNIH UČNIH PRISTOPOV ...

besede za pedagoške pristope, saj le tako s svojim prispevkom informiramo ciljno publiko, ki si tega želi.

\section{Literatura}

Akyuz, D. (2016) Mathematical practices in a technological setting: A design research experiment for teaching circle properties. International Journal of Science and Mathematics Education I4, str. 549-573.

Artigue, M., in Blomhøj, M. (2013) Conceptualizing inquiry-based education in Mathematics. ZDM Mathematics Education 45, str. 797-8Io.

Belland B., Walker A., in Kim N. (2017) A Bayesian Network MetaAnalysis to Synthesize the Influence of Contexts of Scaffolding Use on Cognitive Outcomes in STEM Education. Review of Educational Research 87(6), str. 1042-1081.

Blažič, M., Ivanuš-Grmek, M., Kramar, M., in Strmčnik, F. (2003)

Didaktika: visokošolski učbenik. Novo mesto: Visokošolsko središče, Inštitut za raziskovalno in razvojno delo.

Bloom, W. (2016) Thematic Afternoon: European Didactic Traditions. Presented at ICME-13, $27^{\text {th }}$ of July 2016, Hamburg. Spletna stran: http://www.icmer3.org/thematic_afternoon (pridobljeno 22.2.2020).

Boud, D., in Feletti, G. (1998) The challenge of problem-based learning. London: Kogan Page.

Brown, J. (2017) A metasynthesis of the complementarity of culturally responsive and inquiry-based science education in K-I2 settings: Implications for advancing equitable science teaching and learning. Journal of Research in Science Teaching 54(2), str. II 43-II73.

Demirel, M., in Dağyar, M., (2016) Effects of problem-based learning on attitude: A meta-analysis study. Eurasia Journal of Mathematics, Science \& Technology Education I2(8), str. 2115-2137.

Dogan, H. (2012) Emotion, confidence, perception and expectation: Case of mathematics. International Journal of Science and Mathematics Education I0, str. 49-69.

Drobnič Vidic, A. (2005) Problemsko zasnovan študij pri proučevanju inženirske statistike: doktorska disertacija. Univerza v Ljubljani: Ljubljana.

Drobnič Vidic, A. (20II) Impact of Problem-based Statistics Course in Engineering on Students' Problem-Solving Skills. International Journal of Engineering Education 27(4), str. 885-896.

Drobnič Vidic, A. (2017) Teachers' Beliefs about STEM Education Based on Realisation of the "Energy as a Value" Project in the Slovenian 
School System. International Journal of Engineering Education 33(I), str. 408-419.

Drobnič Vidic, A. (2019) Comparison of problem-based and inquiry-based learning in math Education. The second International Conference on Mathematics, Science and Engineering Education, 8-10. november 2019, North Cyprus.

Feletti, G. (2006) Inquiry based and problem based learning: How similar are these approaches to nursing and medical education? Higher Education Research and Development, 1993, I2(2), str. I43-156.

Filozofska fakulteta Univerze v Ljubljani (2020) Didaktične strategije. Spletna stran: https://www.ff.uni-lj.si/didakticne-strategije (pridobljeno 20.11.2020).

Han, S., Capraro, R., in Capraro, M.M. (2015) How Science, Technology, Engineering, and Mathematics (STEM) Project-Based Learning (PBL) Affects High, Middle, and Low Achievers Differently: The Impact of Student Factors on Achievement. International Journal of Science and Mathematics Education I3(5), str. I089-III3.

Hmelo-Silver, C., Duncan, R.G., in Chinn, C. (2007) Scaffolding and achievement in problem-based and inquiry learning: a response to Kirschner, Sweller, and Clark (2006). Educational Psyhologist 42(2), str. 99-107.

Ibrahim, A. Aulls, M. W., in Shore, B. (2017) Teachers Roles, Students Personalities, Inquiry Learning Outcomes, and Practices of Science and Engineering: The Development and Validation of the McGill Attainment Value for Inquiry Engagement Survey in STEM Disciplines. International Journal of Science and Mathematics Education 15(7), str. 1195-1215.

Jank, W., Meyer,.H. (2006) Didaktični modeli (Didaktische Modelle). Prevedla Javornik, M.. Ljubljana: Zavod Republike Slovenije za šolstvo.

Jenstrle, T. (2017) Tehniška ustvarjalnost pri učenju s poizvedovanjem v 8. in 9. razredu osnovne šole: magistrsko delo. Ljubljana: Pedagoška fakulteta.

Kmetič, S., in Sirnik, M. (ur.). (2010) Posodobitve pouka v gimnazijski praksi. Ljubljana: Zavod Republike Slovenije za šolstvo.

Lee, E., Lee, K., in Park, M. (2019) Developing preservice teacher's abilities to modify mathematical tasks: Using noticing-oriented activities. International Journal of Science and Mathematics Education 17 (5), str. 965-985.

Lesseig, K., Firestone, J., Morrison, J., Slavit, D., in Holmlund, T. (2019) An Analysis of Cultural Influences on STEM Schools: Similarities 
A. DROBNIČ VIDIC • PRIMERJAVA DVEH INTERDISCIPLINARNIH UČNIH PRISTOPOV ...

and Differences Across K-I2 Contexts, 2018. International Journal of Science and Mathematics Education 17 (3), str. 449-466.

Lin, T., Hsu, Y., Lin,S., Changlai, M., Yang, K., in Lai, T. (2012) A Review of Empirical Evidence on Scaffolding for Science Education. International Journal of Science and Mathematics Education Io(2), str. 437-455.

Lotter, C., Yow, J., in Peters, T. (2014) Building a Community of Practice around Inquiry Instruction through a Professional Development Program. International Journal of Science and Mathematics Education I2(I), str. I-23.

Maaß, K., in Artigue, M. (2013) Implementation of inquiry-based learning in day-to-day teaching: a synthesis. ZDM Mathematics Education 45, str. $779-795$.

Marshall, J., Horton, R., Igo, B., in Switzer, D. (2009) K-ı2 Science and Mathematics Teachers' Beliefs about and Use of Inquiry in the Classroom. International Journal of Science and Mathematics Education 7(3), str. 575-596.

Marshall, J., Smart, J., in Horton, R. (2010) The Design and Validation of EQUIP: An Instrument to Assess Inquiry-Based Instruction. International Journal of Science and Mathematics Education 8(2), str. 299-32I.

Oguz-Unver, A., in Arabacioglu, S. (2011) Overviews on inquiry based and problem based learning methods. Western Anatolia Journal of Educational Sciences, Special Issue: Selected papers presented at WCNTSE, str. 303-309.

Partanen, A., in Kaasila, R. (2015) Sociomathematical norms negotiated in the discussions of two small groups investigating calculus. International Journal of Science and Mathematics Education I3(4), str. 927-946.

Petek, D. (20I2) Zgodnje učenje in poučevanje naravoslovja z raziskovalnim pristopom. Revija za elementarno izobraževanje, 4, str. IOI-II 4.

Prince, M., in Felder, R. (2006) Inductive teaching and learning methods: Definitions, Comparisons, and research bases. Journal of Engineering Education 95(2), str. $123-138$.

Rahayu, S., Chandrasegaran, A., Treagust, D. Kita, M., in Ibnu, S. (20II) Understanding Acid-base concepts: Evaluating the efficacy of a senior high school student-centred instructional program in Indonesia. International Journal of Science and Mathematics Education 9, str. I 439-I 458 . 
Rogers, M. P., Abell, S., Lannin, J., Wang, C., Musikul, K., Barker, D., in Dingman, S. (2007) Effective Professional Development in Science and Mathematics Education: Teachers' and Facilitators' Views, Effective Professional Development in Science and Mathematics Education: Teachers' and Facilitators' Views. International Journal of Science and Mathematics Education 5(3), str. 507-532.

Savelsbergh, E., Prins, G., Rietbergen, C., Fechner, S., Vaessen, B., Draijer, D., in Bakker, A. (2016) Effects of innovative science and mathematics teaching on student attitudes and achievement: A meta-analytic study. Educational Research Review 19, str. 158-172.

Shore, B., Chichekian, T., Syer, C., Aulls, M., in Frederiksen, C. (2012) Planning, Enactment, and Reflection in Inquiry-Based Learning: Validating the McGill Strategic Demands of Inquiry Questionnaire. International Journal of Science and Mathematics Education Io(2), str. 315-337.

Spronken-Smith, R. (2012) Experiencing the process of knowledge creation: The nature and use of inquiry-based learning in higher education. The Journal of Geography in Higher Education 2, str. 183-201.

Suban, M. (2017) Učenje in poučevanje matematike s preiskovanjem. Vzgoja in izobraževanje: revija za teoretična in praktična vprašanja vzgojno izobraževalnega dela, 48(4), str. 20-26.

Termania (2020) Strategije pouka. Spletna stran: https://www.termania.net/ slovarji/terminoloski-slovar-vzgoje-in-izobrazevanja/3474484/strategije- pouka?dictionaries $=74 \&$ query $=$ strategija + pouka $\&$ SearchIn $=$ All $($ pridobljeno i8.2.2020).

Thibaut, L., Knipprath, H., Dehaene, W., in Depaepe, F. (2019) Teachers Attitudes Toward Teaching Integrated STEM: the Impact of Personal Background Characteristics and School Context. International Journal of Science and Mathematics Education 17(5), str. 987-1007.

Tomić, A. (1999) Izbrana poglavja iz didaktike. Ljubljana: Center za pedagoško izobraževanje, Filozofska fakulteta.

Tuan, H., Yu, C., in Chin, C. (2017) Investigating the Influence of a Mixed Face-to-Face and Website Professional Development Course on the Inquiry-Based Conceptions of High School Science and Mathematics Teachers. International Journal of Science and Mathematics Education I5 (8), str. I385-I4OI.

Turner, R.C., Keiffer, E.A., in Salamo, G. (2018) Observing Inquiry-Based Learning Environments Using the Scholastic Inquiry Observation Instrument. International Journal of Science and Mathematics Education I6(8), str. I 455-I 478. 
Učni načrt. Matematika (2008) Gimnazija: splošna, klasična in strokovna gimnazija. Ljubljana: Zavod RS za šolstvo. Spletna stran: http://www. mss.gov.si/fileadmin/mss.gov.si/pageuploads/podrocje/ss/ (pridobljeno I3.11.2020).

Vogrinc, J. (2008) Kvalitativno raziskovanje na pedagoškem področju. Ljubljana: Pedagoška fakulteta.

Wing Mui, W. (2013) Connecting mathematics in primary science inquiry projects. International Journal of Science and Mathematics Education II(2), str. 385-406.

Woods, D. R. (2014) Problem-Oriented Learning, Problem-Based Learning, Problem-Based Synthesis, Process Oriented Guided Inquiry Learning, Peer-Led Team Learning, Model-Eliciting Activities, and ProjectBased Learning: What Is Best for You? Industrial \& Engineering Chemistry Research 53(13), str. 5337-5354.

\section{PRILOGA}

Primer PBL / IBL problema in predvidenega postopka reševanja (prirejen iz Drobnič Vidic (2005) za dijake)

Število rezervacij za sedež na letalu. Ameriško letalo, ki leti na relaciji New York - Boston, ima na voljo I2o sedežev. Navadno vsak, ki se želi peljati na omenjeni relaciji, najprej $v$ agenciji rezervira sedez na letalu. Napravljenih je labko največ I2o rezervacij. Ker pa je ta linija zelo obremenjena, so večinoma vsa mesta na letalu zapolnjena z rezervacijo sedeža. Seveda tisti, ki je sedež rezerviral, labko pride na letalo, ali pa ne. Vpovprečju $5 \%$ ljudi, ki rezervirajo sedež na letalu, $v$ resnici ne pride na letalo zaradi tega ali onega razloga. Zato so se $v$ agenciji, ki organizira lete na tej relaciji, odločili, da bodo sprejemali 126 rezervacij namesto 120 rezervacij za let na omenjeni relaciji. Razmisli, zakaj po tvojem mnenju je agencija ravnala tako in utemelji, ali je ravnala prav!

Nestrukturirani problem sproži pri pouku matematike s PBL uvajanje diskretne slučajne spremenljivke in učenje njenih lastnosti po obravnavi verjetnostnega računa. Reševanje problema poteka po modelu 7 korakov v skupinah po 4-6 učencev in učiteljem kot usmerjevalcem skupin $\mathrm{v}$ dveh učnih urah (dveh fazah).

I. FAZA I. korak: Razjasnite pojme ali koncepte, ki niso razumljivi! Pri branju problema učenci pogledajo, če so jasni vsi pojmi. Stavek $\gg V$ povprečju $5 \%$ ljudi, ki rezervirajo sedež na letalu, $v$ resnici ne pride na letalo zaradi tega ali onega razloga.« lahko interpretiramo kot »Verjetnost, da oseba, ki rezervira sedež, ne pride na letalo, je enaka $5 \% . \ll$. 
2. korak: Povejte s svojimi besedami, kaj problem zahteva! »Želimo ugotoviti, zakaj je agencija začela sprejemati natanko 126 rezervacij namesto 120 rezervacij in ali je s tem ravnala prav.« bi se lahko glasilo vprašanje v problemu. 3. korak: Kakšna rešitev ali postopek reševanja vam najprejpade na pamet? (deževanje idej) Deževanje idej pomeni, da v skupini učenci vse ideje, ki se jim porodijo v glavi, tudi povedo. Učenci lahko pridejo tudi do idej, da stevardese odstopijo sedež, če je treba, da je najbrž 6 pilotov in stevardes skupaj... Pogosto učenci, ki se učijo bolj površinsko, poskušajo kar sestaviti rešitev s številkami, ki so na razpolago, zato se pri deževanju idej lahko pojavi tudi ideja: »...zato, ker je $120^{*}$ 0,05 natanko $6 \ll$. Toda, ko poskušajo nato ugotoviti, kaj ta izračun sploh pomeni in ali je agencija ravnala prav, tak preprost račun ne zadošča. Zato je potrebno vsa razmišljanja nekako zapisati in urediti. 4. korak: Spisek možnih razlag oziroma natančnejša analiza rě́evanja. Učitelj skupinam učencev lahko s podvprašanji pomaga do spoznanj:

- da sta po rezervaciji vsakega sedeža le dve možnosti: da oseba pride na letalo ali ne,

- da je vseh sedežev I20 $(n=120)$ in toliko rezervacij,

- da je verjetnost dogodka A, da osebe kljub rezervaciji ni na letalo, enaka $\mathrm{p}=\mathrm{P}(\mathrm{A})=0,05$,

- da je verjetnost negacije dogodka A, da oseba ne pride na letalo, enaka I $-p=0,95$.

Ker se pri vsaki rezervaciji lahko zgodi le dogodek A ali njegova negacija in predpostavimo, da so dogodki za rezervacije neodvisni, lahko učenci uporabijo Bernoullijev obrazec za izračun števila neodvisnih poskusov v zaporedju enakih poskusov: $P(k)=\left(\begin{array}{l}n \\ k\end{array}\right) p^{k}(1-p)^{n-k}$.

Po Bernoullijevem obrazcu učenci izračunajo, da je verjetnost, da natanko ene osebe ni na letalo s I20 sedeži $(\mathrm{k}=\mathrm{I})$, enaka o,oI3. Učitelj nato lahko vpraša (če se učenci ne vprašajo sami): »Ali lahko izračunamo, kolikšna je verjetnost, da dveh oseb, ki sta rezervirali sedež, ni na letalo?« »Verjetnost, da treh oseb ni? « ...«...da šestih oseb ni? « Lahko si razdelijo delo in vsak učenec v skupini izračuna nekaj vrednosti po Bernoullijevi formuli. Zapišejo preglednico z izračunanimi vrednostmi in morda ob pomoči učitelja ugotovijo vse vrednosti, ki jih preglednica vsebuje. Pogosto se namreč zgodi, da učenci pozabijo na število o, ali pa ne vedo, katero je teoretično največje možno število oseb, ki rezervirajo let, a ne pridejo na letalo. Nato učitelj pove, da se omenjena preglednica $z$ vsemi možnimi vrednostmi $k$ in pripadajočimi izračunanimi verjetnostmi $\mathrm{P}(k)$ imenuje verjetnostna shema za slučajno spremenljivko $\mathrm{X}$, ki je odvisna od slučaja. Slučajna spremenljivka X je lastnost, ki jo v problemu preučujemo. $\mathrm{V}$ našem primeru je to število oseb, ki kljub rezervaciji sedeža na letalu s izo sedeži ne pride na letalo. 
5. korak: Oblikovanje učnih ciljev. Učenci po izračunanih nekaj vrednostih skupaj z učiteljem določijo cilje:

- $\quad$ zapisati celotno porazdelitveno shemo za X (to lahko storijo s funkcijo BINOM.DIST s programskim paketom Excel),

- predstaviti verjetnostno shemo s primernim prikazom,

- poiskati v literaturi čim več lastnosti dane slučajne spremenljivke X (vrsta, diskretnost, vsota verjetnosti v verjetnostni shemi, matematično upanje, disperzija),

- $\quad$ izračunati tabelo za letalo z namišljenimi i26 sedeži.

II. FAZA 6. korak: Pridobivanje informacij zunaj skupine. Naloge izpolnjevanja preglednice in prikazovanja tako imenovane binomske slučajne spremenljivke in preučevanja lastnosti si lahko učenci tudi razdelijo in jih opravijo izven pouka. Vse omenjene izračunane karakteristike nato pri pouku združijo, zapišejo in jih predstavijo, ter izračunajo tudi za slučajno spremenljivko $\mathrm{Y}$, ki meri možno število ljudi na namišljenem letalu s 126 sedeži.

7. korak: Poročanje, sinteza, preverjanje pravilnosti novih informacij (interpretacija). Ko učenci dobijo vse rezultate, ugotovijo, da je 6 vrednost slučajne spremenljivke $\mathrm{z}$ največjo verjetnostjo in hkrati matematično upanje $\mathrm{E}(\mathrm{X})=n$ $p=6$ te slučajne spremenljivke $\mathrm{X}$. Vendar nam matematično upanje ne pove vsega o slučajni spremenljivki. Pomemben je tudi standardni odklon (koren disperzije). V našem primeru sicer ni preveč velik $(2,4)$, saj je $\mathrm{D}(\mathrm{x})=n p q=$ 5,7 toda dovolj, da se v veliko izidih dogodi neljuba situacija, ko potnik nima svojega sedeža. Verjetnost, da bo letalo z namišljenimi 126 sedeži preveč polno, je enaka 39 \%, kar je zelo veliko. $S$ takšnim ravnanjem si bo agencija kmalu nakopala nezadovoljstvo potnikov in verjetno agencija s 126 rezervacijami ni storila prav. Za zaključek lahko podamo primer, zakaj je binomska spremenljivka tako pomembna in da je približek za normalno slučajno spremenljivko, ki je zvezna.

Pri IBL $\mathrm{z}$ enakim problemom vpeljemo novo snov: diskretne slučajne spremenljivke. Uporabimo cikel petih E-jev z aktivno uporabo diskusije s celotnim razredom, del učne ure pa učenci lahko delajo tudi v parih ali manjših skupinah ali individualno.

I. Opazovanje situacije / seznanitev s problemom (ang. ENGAGE). Pri branju problema učenci pogledajo, če so jasni vsi pojmi. Učitelj izzove učence, kako bi drugače zapisali stavek: $\gg V$ povprečju $5 \%$ ljudi, ki rezervirajo sedež na letalu, v resnici ne pride na letalo zaradi tega ali onega razloga.« Sprašuje jih, kaj želimo ugotoviti? Povejte s svojimi besedami!

2. Raziskovanje situacije / problema (ang. EXPLORE). Učitelj učencem lahko s podvprašanji pomaga do spoznanj: 
- da sta po rezervaciji vsakega sedeža le dve možnosti: da oseba pride na letalo ali ne,

- da je vseh sedežev I20 $(\mathrm{n}=\mathrm{I20})$ in toliko rezervacij,

- da je verjetnost dogodka A, da osebe kljub rezervaciji ni na letalo, enaka $\mathrm{p}=\mathrm{P}(\mathrm{A})=0,05$,

- da je verjetnost negacije dogodka A, da oseba ne pride na letalo, enaka I $-\mathrm{p}=0,95$.

Kaj se po posamezni rezervaciji lahko zgodi? Ali so dogodki za odpoved rezervacij neodvisni? Kako računamo verjetnosti pri zaporedju neodvisnih poskusov, kjer nas zanima le dogodek A? Kolikšna je verjetnost, da natanko ene osebe ni na letalo s I2o sedeži $(\mathrm{k}=\mathrm{I})$ ? Ali lahko izračunamo, kolikšna je verjetnost, da dveh oseb, ki sta rezervirali sedež, ni na letalo? Verjetnost, da treh oseb ni? ...da šestih oseb ni? Se lahko zgodi, da nihče klub rezervaciji ne pride na letalo? Učitelj učencem lahko razdeli delo in vsak učenec (v skupini) izračuna nekaj vrednosti po Bernoullijevi formuli. Zapišejo preglednico z izračunanimi vrednostmi in morda ob pomoči učitelja ugotovijo vse vrednosti, ki jih preglednica vsebuje. Pogosto se namreč zgodi, da učenci pozabijo na število o, ali pa ne vedo, katero je teoretično največje možno število oseb, ki rezervirajo let, a ne pridejo na letalo. Ne sprašuje le učitelj, ampak postavljajo vprašanja tudi učenci.

3. Razjasnitve pojava ali rešitve problema (ang. EXPLAIN). Učitelj pove, da se omenjena preglednica z vsemi možnimi vrednostmi $k$ in pripadajočimi izračunanimi verjetnostmi $\mathrm{P}(k)$ imenuje verjetnostna shema za slučajno spremenljivko X, ki je odvisna od slučaja. Slučajna spremenljivka X je lastnost, ki jo v problemu preučujemo. V našem primeru je to število oseb, ki kljub rezervaciji sedeža na letalu s I2O sedeži ne pride na letalo. Učenci po izračunanih nekaj vrednostih (skupaj z učiteljem)

- $\quad$ zapišejo celotno porazdelitveno shemo za X (to lahko storijo s funkcijo BINOM.DIST s programskim paketom Excel),

- predstavijo verjetnostno shemo s primernim prikazom,

- določijo vsoto verjetnosti v verjetnostni shemi,

- $\quad$ skupaj z učiteljem določijo matematično upanje, disperzijo, standardni odklon.

4. Zapisovanjespoznanj, argumentiranje in predstavitev (ang. ELABOR ATE). Naloge izpolnjevanja preglednice in prikazovanja tako imenovane binomske slučajne spremenljivke in preučevanja lastnosti si lahko učenci tudi razdelijo. Vse omenjene izračunane karakteristike nato združijo, zapišejo in jih predstavijo. Izračune in nova spoznanja ponovijo na novi situaciji: na slučajni spremenljivki, ki meri verjetnosti na letalu z namišljenimi 126 sedeži. Ko učenci dobijo vse rezultate, ugotovijo, da je 6 vrednost slučajne spremenljivke 
$\mathrm{z}$ največjo verjetnostjo in hkrati matematično upanje $\mathrm{E}(\mathrm{X})=\mathrm{n} \mathrm{p}=6$ te slučajne spremenljivke X. Vendar nam matematično upanje ne pove vsega o slučajni spremenljivki. Pomemben je tudi standardni odklon (koren disperzije). V našem primeru sicer ni preveč velik $(2,4)$, saj je $\mathrm{D}(\mathrm{x})=\mathrm{npq}=5,7$ toda dovolj, da se v veliko izidih dogodi neljuba situacija, ko potnik nima svojega sedeža. Verjetnost, da bo letalo z namišljenimi 126 sedeži preveč polno, je enaka 39 $\%$, kar je zelo veliko. $S$ takšnim ravnanjem si bo agencija kmalu nakopala nezadovoljstvo potnikov in verjetno agencija s 126 rezervacijami ni storila prav. 5. Ocena opravljenega dela (ang. EVALUATE). Učenci ocenijo pomen uvajanja diskretne slučajne spremenljivke, zakaj je binomska spremenljivka tako pomembna in da je približek za normalno slučajno spremenljivko, ki je zvezna. 